\title{
Microbiome First Medicine in Health and Safety
}

\author{
Rodney R. Dietert
}

check for

updates

Citation: Dietert, R.R. Microbiome First Medicine in Health and Safety. Biomedicines 2021, 9, 1099.

https://doi.org/10.3390/

biomedicines 9091099

Academic Editor: Amedeo Amedei

Received: 27 July 2021

Accepted: 23 August 2021

Published: 27 August 2021

Publisher's Note: MDPI stays neutral with regard to jurisdictional claims in published maps and institutional affiliations.

Copyright: (C) 2021 by the author Licensee MDPI, Basel, Switzerland. This article is an open access article distributed under the terms and conditions of the Creative Commons Attribution (CC BY) license (https:// creativecommons.org/licenses/by/ $4.0 /)$.
Department of Microbiology and Immunology, Cornell University, Ithaca, NY 14853, USA; rrd1@cornell.edu

Abstract: Microbiome First Medicine is a suggested 21st century healthcare paradigm that prioritizes the entire human, the human superorganism, beginning with the microbiome. To date, much of medicine has protected and treated patients as if they were a single species. This has resulted in unintended damage to the microbiome and an epidemic of chronic disorders [e.g., noncommunicable diseases and conditions (NCDs)]. Along with NCDs came loss of colonization resistance, increased susceptibility to infectious diseases, and increasing multimorbidity and polypharmacy over the life course. To move toward sustainable healthcare, the human microbiome needs to be front and center. This paper presents microbiome-human physiology from the view of systems biology regulation. It also details the ongoing NCD epidemic including the role of existing drugs and other factors that damage the human microbiome. Examples are provided for two entryway NCDs, asthma and obesity, regarding their extensive network of comorbid NCDs. Finally, the challenges of ensuring safety for the microbiome are detailed. Under Microbiome-First Medicine and considering the importance of keystone bacteria and critical windows of development, changes in even a few microbiota-prioritized medical decisions could make a significant difference in health across the life course.

Keywords: chronic disorders; inflammation; human superorganism; holobiont; microbiome; multimorbidity; microimmunosome; polypharmacy; drug safety; sustainable healthcare

\section{Introduction}

The human superorganism (also called the human holobiont) is a composite organism composed of the human mammalian body combined with the human resident microbiota (the bacteria, archaea, viruses, and fungi) along with their genes. The various microbiomes inhabit our body across several different locations (e.g., skin, gut, airways, urogenital tract, breast tissue, breast milk). The vast majority of our trillions of microbes are not just friendly to our body but are essential. They provide critical metabolic, physiologic, regulatory and host defense functions (e.g., colonization resistance) as well as vitamins that are needed for life and health [1]. The human microbiota also impacts much of the body's neurochemical and hormone production, and because of their direct and indirect regulation of neurological function (e.g., via small molecules and epigenetic control), it is sometimes unclear who is really in charge when it comes to the human body $[2,3]$.

Humans are not unique in being mainly microbial in genetic composition. Most higher organisms on earth operate as composites or superorganisms. That is a fundamental nature of much of life on earth (which is primarily a microbial planet) [4]. While the development and function of all of our physiological systems are influenced by the human microbiome, the interaction between the microbiome and the immune system is perhaps the most critical [5]. Part of the critical nature of the microbiome-immune interaction has to do with location. The body sites inhabited by our microbes are the same locations that house a preponderance of our immune cells. Most of these happen to be the mucosal tissues (gut, airways, urogenital tract). The replacement of our immune cells immediately juxtaposed to the microbiota is not happenstance. In fact, the microbes have a lot to do with the recruitment and migration processes that place the immune cells as monitors and sensors for the status of the microbiome [6]. 
This is particularly evident given that the majority of human immune cells are located in the gut [7], and many of these are separated from the gut microbiota by a one-cell thick epithelial lining and a mucin barrier. The gastrointestinal system is open to the outside world via the mouth and anus. Within the gut, food, drugs, and environmental chemicals are first encountered by the gut microbiota where they are filtered and metabolized for the benefit (or sometimes the detriment) of both the microbiota and our internal tissues and organs.

\section{The Microimmunosome: A Systems Biology Therapeutic Target}

In the gut, the integrity of both the one-cell thick gut epithelial barrier and the mucin lining is critical. They physically separate gut microbes including pathobionts from the underlying immune system, but they also allow bidirectional communication between the two. When something goes wrong with one part of this systems biology unit, (e.g., changes in the microbiota that cause a degradation of the mucin layer), the entire system can be in jeopardy. Microbial dysbiosis can lead to an exposed epithelial barrier. When this barrier is damaged and breached by pathobionts, immune inflammation is initiated and, if uncorrected, local as well as systemic pathology can ensue. In the gut, this is precisely how diseases like metabolic syndrome begin.

Because of the inter-connectivity among the gut microbiota, mucin layer, gut barrier and underlying immune system, it is operationally useful to approach these combined factors as a single systems biology unit. This unit has been termed the microimmunosome [8]. Beyond the gut, the same dynamic exists in the skin, airways, and urogenital tract. These locations (e.g., skin, airways) where microbes meet our immune cells have their own microimmunosomes and should also be approached as well-oiled systems biology units.

When changes occur (e.g., diet, drugs, environmental conditions, lifestyle, stress), it is important that the changes are beneficial for the overall microimmunosome to avoid unintended consequences. For example, a NSAID designed to lower mediators of immune inflammation that has a side effect of producing microbial dysbiosis can easily end up damaging the gut and producing long term increases in both the risk of infections and immune inflammation. Short term gains in modulation of inflammation can boomerang to longer term systemic problems.

In medicine and healthcare, it is the microimmunosome that is the ultimate target. Changing one element of the systems biology unit will inevitably impact the other components of the unit. The physician needs to be aware of this relationship and manage prevention and therapies accordingly.

\section{The Immune System and Superorganism Integrity}

The discovery of the microbiome and its role in molding our immune development and function has led to a 21st century rethinking of what the immune system is really designed to do. No longer is the immune system viewed as put into existence to detect and kill all microbes. Instead, the immune system grows up with the developing human microbiome, prunes the microbiome, surveils the microbiome, directly reflects microbiome development and status, and responds accordingly when the microbiome is damaged and dysbiotic. Damage to the microbiome can occur via high fat or sugary diets, toxic food additives (e.g., emulsifiers), toxic environmental chemicals (e.g., pesticides) and even microbe-damaging drugs (e.g., proton pump inhibitors [8]]. Of course, incompleteness of or damage to the human microbiome predictably leads to immune-inflicted damage to our bodies $[9,10]$.

There is a new 21st century dogma that views humans as mainly microbial (genetically) and fundamentally a superorganism (where our body is a composite of thousands of different species). This dogma changes the very definition of what it means to be healthy. Being healthy within our 21st century understanding means existing in a specific microberich state. In contrast, illness is the state of being out-of-balance and biologically incomplete. We are ill when we become something akin to a damaged coral reef. Illness is the state of 
being poorly microbially balanced (often lacking certain commensal microbes) and lacking the colonization resistance necessary to control against pathobiont attack [11].

As for the immune system, we need to upgrade our thinking to adjust to immune biology and medical support in this era of the superorganism. The same approaches that we pursued in the 20th century no longer hold. It is time to discard 20th century dogmas about microbes and the immune system and to embrace the microimmunosome as a focal point when it comes to preventing and managing diseases [12].

It should be noted that many 20th century-established, medically-approved practices are an ongoing problem. They are a problem because they prevent patients from acquiring a healthy microbiome and/or deplete and damage their existing microbiome [13]. Dietert [13] considered the initial sequence of disease-promoting events. Figure 1 illustrates how our current single-species-oriented medical management can lead the child toward a healthcare intensive, illness-filled life.

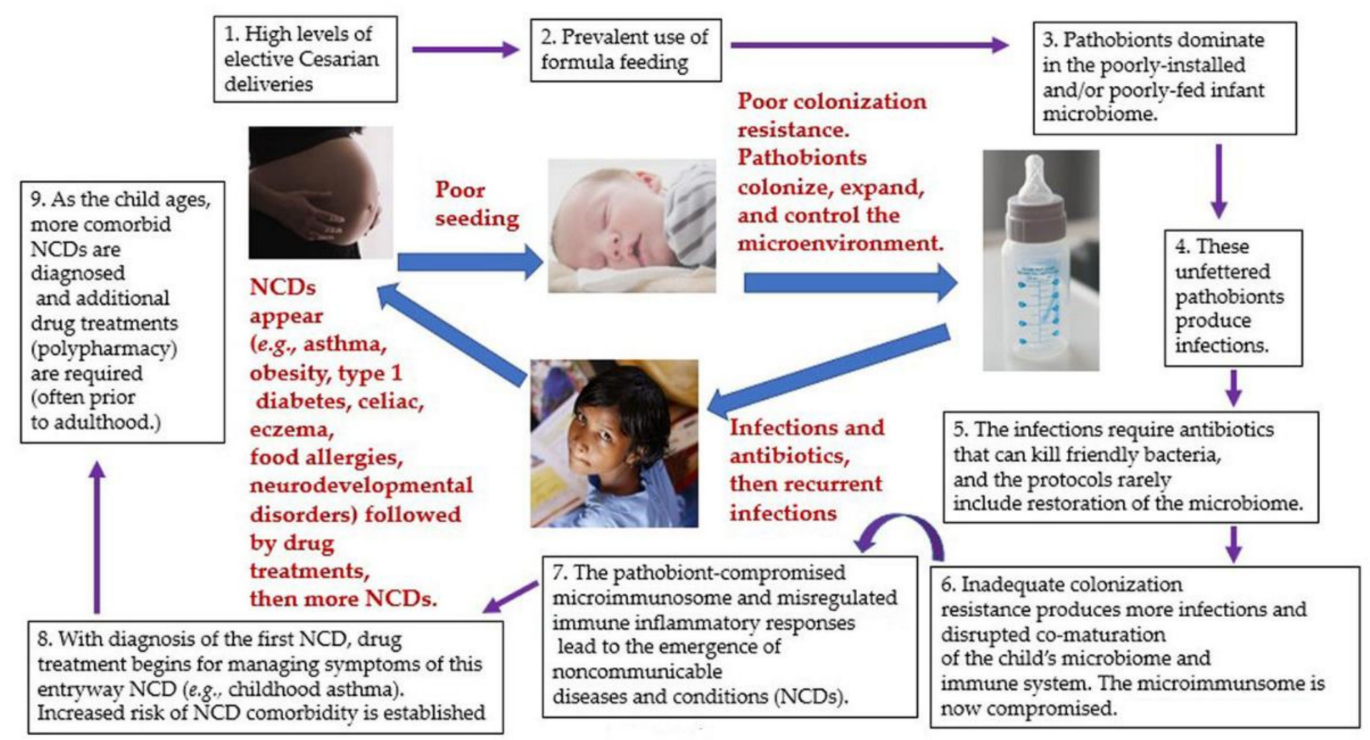

Figure 1. Lack of focus on the microbiome promotes a pathobiont-dominated microbiome, a damaged microimmunosome, misregulated inflammation, and the likelihood of multimorbid NCDs over the life-course.

This disturbing sequence of events has given us: (1) ever-increasing numbers of chronic diseases across the life course, (2) polypharmacy, (3) increased risk of life-threatening infections, (4) reduced human capacities, (5) reduced quality of life, (6) increased need for caregivers, and (7) unsustainable medical costs. There is a better way.

\section{Introducing Microbiome First Medicine}

This paper introduces the concept of Microbiome First Medicine as a strategy to reverse the NCD epidemic and move us toward sustainable healthcare. Because the human microbiome carries the vast majority of our genes [14], fundamental human biology dictates that the microbiome should be front and center in any preventative or therapeutic medical plan. It is counterproductive to focus on protection of health and treatment of chronic diseases involving a patient's internal organs/physiological systems, while at the same time failing to address microbiome dysbiosis in the human superorganism.

\section{NCDs: Human Illness and Death}

NCDs can be life changing and life threatening. They are the leading cause of global death ( $71 \%$ of all deaths as reported by the World Health Organization) [15]. But beyond the eventual cause of death for most individuals, these diseases and conditions both restrict function and activities and can require specific medications that may be prescribed for life. One example of this is statins prescribed to lower cholesterol [16]. 
Many diseases such as Alzheimer's disease, Parkinson's disease, dementia, multiple sclerosis, cystic fibrosis, fibromyalgia, autism, stroke, and cancer can require caregivers. This can be a significant burden for families in terms of financial obligations and stress. In fact, caring for patients with NCDs can affect the health and well-being of the caregivers $[17,18]$.

The epidemic of NCDs over the past several decades has been seemingly tolerated within healthcare as we became an all too passive observer of NCD proliferation. Progress in medical specialties involving single organs/physiological systems and drugs medically coded for disease-specific use can mask a bigger picture. New NCD distinctions have been teased out, and new medications were developed for each new diagnosis. Unfortunately, with NCDs as a growth industry, core causes, and dysfunctional commonalities among NCDs became largely lost in the weeds. Yet, potential cures reside in those commonalities among NCDs (e.g., microbiome dysbiosis and misregulated inflammation). That is why, if healthcare is to be sustainable, it needs to focus on the patient from the outside-in beginning with restoration of the microbiome.

\section{The Immune System as a Manager of Superorganism Integrity}

The primary function of the immune system is to identify and survey the components of the human superorganism and to ensure that the body's tissues and organs maintain integrity, structure, and function. Tissues and organs have to function within certain limits and commensal microbes need to be tolerated while pathobionts are held in check. It is useful to think of the different human microbiomes as another organ or tissue that the immune system has to survey and manage.

The concept of maintaining tissue integrity as the core function of the immune system was described by Dembic [19] and is simple enough. Of course, our tissues are different, and have diverse functions, while specialized resident cells of the immune system must grapple with that diversity. However, when tissue integrity includes the human microbiome and trillions of essential microbes doing their job, ensuring tissue integrity becomes even more challenging.

\section{NCDs as Mainly Immune-Inflicted Diseases}

The majority of global deaths worldwide are caused by chronic diseases also known as noncommunicable diseases and conditions (NCDs). These are the prevalent diseases of asthma, heart disease, obesity/diabetes/metabolic syndrome, cancer, neurological degenerative conditions, autoimmune diseases, allergic diseases and inflammatory conditions (arthritis, psoriasis, frailty, etc.). It was recently recognized that the term noncommunicable is less useful than previously thought. At least some of the NCDs appear to be transferable (i.e., communicable) to others via specific pathobionts when the recipient's microbiome is compromised and receptive [reviewed in 12]. Therefore, noncommunicable appears to be contextual and not absolute.

NCDs are inherently immune-inflicted in nature. The immune system literally destroys parts of the body in response to organismal composite imbalances. The inappropriate immune response is the body's attempt to "defend and repair" the human superorganism in the face of systems biology disruptions connected to microbiome dysbiosis. To exist and persist, these chronic diseases, while in many different tissues, have a common feature. They require ongoing, unresolving, immune-driven inflammation. The misregulated immune system does not like what is presented and attacks with auto-destruction as a result [20].

Note that many medical/pharmacological treatments for chronic disease such as asthma, heart disease, inflammatory bowel disease, etc. attempt to modulate inflammatory mediators and their impact on tissues and organs. Few if any treatments actually go to the heart of the cause: misregulated inflammation resulting from human superorganism dysbiosis. 


\section{Two High-Impact Examples of NCDs}

To highlight the risk of receiving an NCD diagnosis within our current healthcare system, two common NCDs are considered: asthma and obesity. These are two highly prevalent diseases/conditions with a predictable path of both treatments and future comorbid diseases.

\subsection{Asthma}

Asthma is a chronic respiratory disease of both allergic and non-allergic origins. While it can emerge at any time in life, the first episode of asthma is often preceded by one of several generic respiratory virus infections [21]. This disease is among the earliest group of NCDs to be seen during childhood. Asthma is part of the allergic triad of diseases, which includes allergic rhinitis (hayfever), and atopic dermatitis. More recently, food allergies have been added to that allergic complex and have become another important childhood-onset disease.

Table 1 shows examples of 36 comorbid NCDs where asthmatics are at a higher risk of being diagnosed with these NCDs vs. the general population [22-58]. The 36 comorbidities of asthma range well beyond the allergic conditions. Remarkably, they include autoimmune, metabolic, cardiovascular, neurobehavioral, neurodegenerative, endocrine, reproductive, systemic conditions (e.g., mast cell activation), cancer (e.g., lung) and even what are termed end-stage diseases (e.g., frailty). The asthmatic child has a life course that is literally bookended by NCDs unless and until we approach medicine and healthcare differently.

Asthma is one of the diseases where symptoms are controlled often by multiple prescribed medications. But actual cures have evaded us. This disease has several different endotypes usually differing in the mix of the immune system components that infiltrate the lungs and mediate inflammation and pathology in the airways. In severe forms, asthma is a truly debilitating disease. A recent finding is that asthma can be caused by and exacerbated by a pathobiont (a potentially infectious agent). In this case it is the gram-positive bacterium, Staphylococcus aureus (Staph A). The bacterium can exist in a hospital-associated, multi-drug resistant form called Methicillin-resistant Staphylococcus aureus (MRSA). When Staph A is a predominant colonizer in the nasal passages of infants, those infants are at a higher risk of childhood asthma [59]. But when the microbiome is healthy, other bacteria can block Staph A from taking up residence via colonization resistance [60,61]. Managing the infant microbiome to optimize colonization resistance against Staph A is one way to reduce the risk of childhood asthma. But this requires, Microbiome First Medicine.

While asthma is a significant enough life burden by itself when left uncured, it is the high risk of other comorbid NCDs that makes a pediatric asthma diagnosis a major lifethreatening event. Asthma and other allergic diseases should be considered as an entryway ticket to what constitutes a web of additional childhood- and adult-onset comorbid NCDs.

\subsection{Obesity}

Obesity is one of the major conditions that gives rise to a myriad of comorbid, inflammation driven, chronic diseases particularly as aging progresses [62,63]. Table 2 illustrates examples of 43 comorbid NCDs for obesity [64-95]. The obese population carries one of the highest risks for multiple future NCDs of any disease-burdened cohort. As a component of metabolic syndrome, obesity can arise at any time in life. However, it is one of the NCDs that is frequent in childhood and, as a result, can be a disease burden and comorbid disease risk for most of the life course [96]. 
Table 1. Comorbidities of Asthma.

\begin{tabular}{|c|c|}
\hline Disease, Condition, and/or Extrapulmonary Symptom & Reference(s) \\
\hline Allergic rhinitis & [22] \\
\hline Atopic dermatitis & [23] \\
\hline Food allergies & {$[24,25]$} \\
\hline Chronic obstructive pulmonary disease (COPD) & [26] \\
\hline Chronic sinusitis & {$[27,28]$} \\
\hline Obesity & [29] \\
\hline Depression & [26] \\
\hline Anxiety & [26] \\
\hline Mood swings & [30] \\
\hline Attention Deficit Disorder & [31] \\
\hline Fatigue & [30] \\
\hline Gastro-esophageal reflux disease (GERD) & [32] \\
\hline Osteoarthritis & [33] \\
\hline Vocal cord dysfunction & [34] \\
\hline Stomach ulcers & [35] \\
\hline Nasal polyps & [36] \\
\hline Frailty & [37] \\
\hline Hypertension & [38] \\
\hline Skeletal muscle wasting/Sarcopenia & [39] \\
\hline Mast cell activation syndrome & [40] \\
\hline Hormone imbalances/disorders & {$[41,42]$} \\
\hline Type 2 diabetes & {$[43]$} \\
\hline Obstructive sleep apnea & {$[44]$} \\
\hline Insomnia/sleep disorders & {$[45,46]$} \\
\hline Ischemic heart disease & [47] \\
\hline Hypoxia & [48] \\
\hline Stroke & [49] \\
\hline Acute myocardial infarction & [50] \\
\hline Posttraumatic Stress Disorder (PTSD) & [51] \\
\hline Myasthenia gravis & [52] \\
\hline Lung cancer & [53] \\
\hline Allergic bronchopulmonary aspergillosis (ABPA) & [54] \\
\hline Type 1 diabetes 1 & [55] \\
\hline Metastasized breast cancer $^{2}$ & [56] \\
\hline Eosinophilic granulomatosis with polyangiitis (vasculitis) ${ }^{3}$ & [57] \\
\hline Coronary heart disease ${ }^{4}$ & [58] \\
\hline
\end{tabular}

${ }^{1}$ Some subtypes of asthma in children. ${ }^{2}$ The metastasized form of breast cancer is more likely in asthmatics because of inflammation-promoted metastasis. ${ }^{3}$ Associated with severe asthma. ${ }^{4}$ More frequent in females with adult-onset of asthma.

Obesity is a significant contributor to end stage diseases such as chronic kidney disease [97] and frailty (a pro-inflammatory end stage condition associated with muscle loss) [98]. Among the immune changes that help to spread obesity, macrophage populations undergo significant changes that can lead toward the various manifestations of metabolic syndrome [99]. One of the theories behind inflammation spread with obesity is that adipocyte-derived extracellular vesicles may disrupt redox signaling and facilitate the spread of inflammation to the cardiovascular system [100].

Similar to the case with asthma, application of Microbiome First Medicine in obesity could interrupt our current life course march toward increasing numbers of comorbid diseases. Because of the web of connected diseases, if we do nothing different in medicine and continue to manage NCD symptoms rather than restoring integrity to the microbiome and immune system, the NCD epidemic will only continue if not get worse. 
Table 2. Examples of Comorbidities of Obesity.

\begin{tabular}{|c|c|}
\hline Disease or Condition & Reference \\
\hline Type 2 diabetes & [64] \\
\hline Hypertension & [65] \\
\hline Coronary artery disease & [66] \\
\hline Atherosclerosis & [67] \\
\hline Polycystic ovary syndrome (PCOS) & [68] \\
\hline Urinary stress incontinence & [69] \\
\hline Osteoarthritis & [70] \\
\hline Dyslipidemia & [71] \\
\hline Obstructive sleep apnea & [72] \\
\hline Sleep fragmentation & [73] \\
\hline Nonalcoholic fatty liver disease (NAFLD) & [74] \\
\hline Nonalcoholic hepatic steatosis (NAHD) & [75] \\
\hline Asthma & [76] \\
\hline Rheumatoid arthritis & [77] \\
\hline Crohn's disease (in women) & [78] \\
\hline Hearing loss & [79] \\
\hline Deep vein thrombosis & [80] \\
\hline Infertility & [81] \\
\hline Frailty & [82] \\
\hline Alzheimer's disease & [83] \\
\hline Gout & [84] \\
\hline Hypothyroidism & [85] \\
\hline Dementia & [86] \\
\hline Multiple sclerosis & [87] \\
\hline Schizophrenia (cortical thickness reduction) & [88] \\
\hline Chronic obstructive pulmonary disease (COPD) & [89] \\
\hline Depression & [90] \\
\hline Anxiety & [91] \\
\hline Psoriasis & [92] \\
\hline Attention Deficit Disorder & [93] \\
\hline Chronic kidney disease & [94] \\
\hline Leukemia & [95] \\
\hline Uterine cancer & [95] \\
\hline Gallbladder cancer & [95] \\
\hline Thyroid cancer & [95] \\
\hline Cancer of the cervix & [95] \\
\hline Hepatic cancer & [95] \\
\hline Ovarian cancer & [95] \\
\hline Postmenopausal breast cancer & [95] \\
\hline Colon cancer & [95] \\
\hline Kidney cancer & [95] \\
\hline Pancreatic cancer & [95] \\
\hline Rectal cancer & [95] \\
\hline
\end{tabular}

\section{Marching to Multimorbidity and Polypharmacy through a Web of NCDs}

The outcomes shown in Tables 1 and 2 can only be described as unacceptable results stemming from the medical mismanagement of two epidemic NCDs, asthma and obesity. It is possible that most asthmatics and obese patients and their healthcare providers are not fully aware of this reality. Nor are they necessarily aware that asthma and obesity are themselves linked together as bidirectionally-shared comorbidities.

A look beyond asthma and obesity to gastrointestinal (e.g., inflammatory bowel), neurological (e.g., multiple sclerosis), metabolic (e.g., type 2 diabetes), reproductive (PCOS), cardiovascular (e.g., atherosclerosis), and dermal (e.g., psoriasis) NCDs would lead one to conclude that most NCDs have a large number of comorbidities, and that current medical management of these diseases has produced similar outcomes as illustrated for asthma and obesity. For example, when inflammatory bowel disease and psoriasis were examined for comorbid diseases more than a decade ago, serious comorbid NCDs were identified [101]. 
A second finding was that many NCDs share depression, sleep disorders, and atherosclerosis as comorbidities [101]. More recent evaluations of inflammatory bowel disease and psoriasis found that both diseases have double digit NCD comorbidities [102-104].

The problem with the NCD epidemic is not just the fact that 71 percent of people globally die of NCDs [15]. It is what happens along the way between the cradle and the grave. The progression towards this type of death inevitably runs through multimorbidity (carrying two or more NCDs) and polypharmacy. The prevalence of multimorbidity among different populations in the U.S. was determined through the National Health and Nutrition Examination Survey (NHANES) and could be compared across several different years [105]. In the 2013-2014 survey, the prevalence of two or more NCDs in all adults (age 20 and higher) was 59.6\%. For the young adult 20-44 age group, more than one third had multimorbidity (37.5\%), in the $45-64$ age group it was $70.6 \%$, and for the age 65 and older group, it was, remarkably, $91.8 \%$. Clearly, many U.S. adults are aging over decades carrying a significant NCD burden. These diseases are not being cured. Rather, the symptoms are being managed amid what is a growing disease burden.

Polypharmacy is not without its own problems. Beside the fact that it is not sustainable at a global level in treating multi-comorbid-burdened patients, evidence suggests that polypharmacy is associated with reduced cognitive function [106]. Hence, reduced quality of life and increased caregiver needs are the rewards for additional prescriptions.

\section{Drug Safety for the Human Superorganism}

The problem with the NCD epidemic and polypharmacy is not simply the number of prescription drugs that an individual accumulates with aging, it is that the existing drugs were also produced and vetted with only the human mammal in mind. The patient was the human mammal, and the safety of drugs medically coded for each NCD did not extend to the human microbiome [107].

Table 3 shows examples of commonly used drugs that interact with and in many cases damage the human microbiome [108-123]. In a recent investigation, approximately half of all commonly used drugs affected the microbiome [110]. For some drugs, metabolism by the microbiota is required for the drug's active form to be produced. The human microbiome varies such that if a physician does not know the patient microbial composition, the appropriateness of the drug and/or the drug dose is also unknown.

In some cases, such as with the cardiac drug, digoxin, the lack of knowledge about the patient's microbiome could result in the administered drug being problematic and potentially lethal [126]. The levels of a single gut bacterium, Eggerthella lenta, determine the pharmacokinetics of digoxin (see Table 3). This bacterium can metabolically inactivate digoxin and affect the internally-delivered dose of the drug [126]. Hence, the internal dose of the active drug can differ significantly from the physician-delivered dose. This is where personalized, Microbiome First Medicine becomes important. The physician needs to know the patient's microbial metabolic activity for digoxin in order to be able to prescribe an effective, non-lethal dose.

Another pattern of drug-microbiome interactions is when the drug selectively kills part of the microbiome. Selective killing of commensal bacteria can damage colonization resistance and enable other microbes to grow in an unrestricted manner. Loss of colonization resistance significantly affects the risk of pathobiont-driven infections (e.g., MRSA, Clostridioides difficile). This can happen with common drugs such as non-steroidal anti-inflammatory drugs (NSAIDs) [127] and proton-pump inhibitors [128].

There are two take home messages from this information. (1) For patient safety and drug efficacy, drugs should be prescribed under the personalized medicine rubric with the patient's microbiome in mind. (2) All new drug candidates should be demonstrated to be safe for the human microbiome. 
Table 3. Examples of Drug Interactions with the Microbiome.

\begin{tabular}{|c|c|c|}
\hline Drug/Drug Category & $\begin{array}{c}\text { Damages } \\
\text { and/or Interaction(s) }\end{array}$ & Reference(s) \\
\hline Digoxin (Cardiovascular) & Internal drug dose affected by gut bacterium, Eggerthella lenta & [108-110] \\
\hline $\begin{array}{l}\text { Non-steroidal anti-inflammatory } \\
\text { drugs (NSAIDs) }\end{array}$ & $\begin{array}{l}\text { Produces NSAID-specific enteropathy, damage to specific microbiota that protect against } \\
\text { gastric enteropathy; Probiotics may help functionality }\end{array}$ & [111-113] \\
\hline Proton Pump Inhibitors & Damages approximately $20 \%$ of the gut microbiota; increases the risk of enteric infections & {$[112,114,115]$} \\
\hline SSRI Antidepressants & $\begin{array}{l}\text { SSRIs act like antibiotics completely restructuring the gut microbiome causing loss of } \\
\text { some needed species and overgrowth of others }\end{array}$ & {$[112,116,117]$} \\
\hline Oral steroids & Can cause overgrowth of obesogenic, methogenic bacteria & [112] \\
\hline Metformin (Type 2 diabetes) & Increased growth of E. coli species with increased risk from pathobionts & {$[112,118]$} \\
\hline Laxatives (with polyethylene glycol) & Reduced diversity of the gut microbiome & [119] \\
\hline Beta Blockers & Increase in pathobiont for dental caries, Streptococcus mutans & [118] \\
\hline H1 inhibitor antihistamines & $\begin{array}{l}\text { Increase in Clostridium bolteae a pathobiont associated with both gut and neurotoxic } \\
\text { metabolites }\end{array}$ & {$[118,120]$} \\
\hline $\begin{array}{l}\text { Platelet aggregation inhibitors } \\
\text { (aspirin) }\end{array}$ & $\begin{array}{l}\text { Increases in several Streptoccocus and Clostridial pathobionts and reduction in a major } \\
\text { GABA producer (Bifidobacterium adolescentis) }\end{array}$ & {$[118,121]$} \\
\hline Opioids (Pain management) & The gut microbiome becomes dysbiotic and can lock in the dependency. & {$[122,123]$} \\
\hline Cancer therapeutics & $\begin{array}{l}\text { The gut microbiome can be altered by cancer therapeutics and this can subsequently } \\
\text { affect immune anti-tumor effectiveness. Also the cancer drug, cyclophosphamide, has a } \\
\text { better prognosis for lung cancer patients when the patients carry the bacterium, } \\
\text { Enterococcus hirae }\end{array}$ & {$[124,125]$} \\
\hline
\end{tabular}

\section{Microbe Management: Keystone Species and Cooperative Metabolic Communities}

At first glance the idea of practicing microbiome first medicine (optimizing the human body working from the microbiome inward) might seem daunting. After all, the human microbiome is complex with trillions of microbes taking up residence in and on various parts of our body.

But there is evidence that benefit can come from medically simplifying the microbiome. A starting point is to divide the specific microbiome (i.e., gut, skin, airways, urogenital tract) into two basic groups: (1) the keystone species and (2) communities of microbes, or metabolic modules, that together create a useful metabolic environment in a specific body site. The keystone species are indispensable microbial species that each provide a unique function. Prolonged damage to a keystone species usually results in disease. In contrast, the communities of microbes (site-specific metabolic modules) provide important functions based on group interactions. Specific microbes within a metabolic module are often interchangeable. Within these modules, significant health risks occur when there are changes in group function rather than changes in a single microbial species. The metabolic modules are identified using approaches such as metabolomics [129] and metabologenomics [130]. Analysis of a patient's keystone species and microbial metabolic module status can guide physicians on making adjustments to both the microbiota and supportive microbial food sources (prebiotics/diet).

Keystone species in the microbiome are specific, often unique microbes that provide a vital function. They are largely irreplaceable, and the function provided is usually a tipping point between health and disease. If the physician, healthcare provider, and patient know nothing else about the microbiome, they should know the status of keystone species. While there are several keystone species among the body's microbiomes, two gut keystone bacteria deserve special mention: Bifidobacterium longum ssp infantis and Akkermansia mucuniphila. B. infantis is both the premier metabolizer of the food component of human breast milk [human milk oligosacharrides (HMOs)], and it is a pivotal orchestrator of infant immune maturation [131,132].

A. muciniphila is the premier regulator of the gut's mucin layer, which protects the one-cell thick gut barrier and helps to guard against improper immune activation and hyperinflammation [133]. To prevent childhood and adult NCDs, the pediatrician needs 
to ensure that these keystone functions are in place in the infant to balance the immune system, protect the gut barrier, and reduce the risk of immediate infections followed by future NCDs.

Cooperative metabolic communities provide site-specific metabolic modules that optimize a variety of functions in specific regions of the body site. In the case of these communities of microbes, some of the parts (e.g., bacterial species) may be redundant or interchangeable. But a combination of microbes with a useful mix of genes provides functions ranging from colonization resistance against pathobionts, to neuroactive peptide synthesis, to short chain fatty acid (SCFA) production, to bile acid metabolism. Such community microbial function is significant for the patient's overall physiology and wellbeing (i.e., brain, immune, gut, liver, and other tissue functions). Not surprisingly for cooperative metabolic communities, it does come down to "location, location, location" and microbial communities can create healthful ecological niches within the human gut. Here is where metabolically-driven readouts aid the physician/healthcare provider. Because the microbiome, its genes, and metabolic status are fully adjustable, the physician and patient are both empowered and poised to make useful, impactful changes. But they can only do this if they know to look to the microbiome first and foremost, and know what adjustments would bring the patient into functional balance.

\section{Blocking Pathobionts to Protect against NCDs}

Blocking pathobionts using a multi-level, front-line defense known as colonization resistance is beneficial across the entire spectrum of disease challenges. This is one of the most effective yet under-utilized tools within current preventative medicine. Under Microbiome First Medicine, this tool would become routine across medical specialties with the immediate effect of reducing the need for antibiotics.

Effective colonization resistance goes well beyond just stopping infectious diseases from happening. As discussed by Dietert and Dietert [12], the dogma stating that there is a "boundary" between NCDs and communicable (infectious) diseases is proving to be more like an outdated 20th century construct than a 21st century reality. Many NCDs are actually communicable within the context of the dysbiotic microbiome [12,134]. It is now clear that microbiome dysbiosis not only allows pathobionts to breach barriers and infect, but that many of those same pathobionts have the capacity to cause quite specific NCDs when the microimmunosome has been compromised.

As introduced in Dietert [135] and expanded here, at least three examples exist of pathobiont-produced NCDs are known. The gram-positive bacterium Staphylococcus aureus (Staph A) (carried in the nose, skin, and the urogenital tract) can directly promote asthma using multiple direct and indirect changes to the immune system $[59,136]$. Adherentinvasive Escherichia coli is another human pathobiont that can produce the inflammatory bowel disease "NCD" under the circumstances of microbiome dysbiosis [137].

Beyond these two examples, Rath et al. [138] present a list of what have been termed pathogenic functions among various human pathobionts. Many of these pathobionts overproduce metabolic products that result in NCDs. A prime example of this is the production of the microbial metabolite trimethylamine (TMA), which can lead to cardiovascular disease (particularly atherosclerosis), type 2 diabetes, and renal disease [138]. TMA is at the heart of the conversion of macrophages into "foam cells," which sit at the center of atherosclerotic plaques. TMA is significantly associated with Enterobacteriaceae bacteria with a subset of Clostridiales contributing community production of the metabolite $[139,140]$.

\section{Critical Windows for Programming Health vs. Disease}

Early prenatal and postnatal development is known to be a period of vulnerability during which significant programming occurs for childhood and adult health vs. disease [141,142]. This idea originated with what became known as the Barker hypothesis when Robert Barker (a British MD) demonstrated that prenatal development could program for later-life cardiovascular disease [143]. Soon, it was clear that the programming window 
extended to significant periods of postnatal development and included programming for most NCDs [144]. For this reason. attention to the infant microbiome status and immune co-maturation process is critical for preventative healthcare.

One problem is that Clostridiales and Enterobacteriaceae bacteria along with Staphylococcus are among the original colonizers in premature babies and immediately after birth in full term newborns [145]. It is critical that these founding bacteria not persist, and that they be replaced by the Bifidobacterium group and in particular, B. longum spp infantis. B. infantis must be introduced into the infant gut for two reasons. First, the prior colonizers contain potential pathobionts and TMA producers. B. infantis lowers the $\mathrm{pH}$ providing colonization resistance against the pathobionts and preventing enteric inflammation from occurring [146,147].

This is a critical developmental window for both the gut microbiome and the immune system. A priority for medical care should be to ensure that the newborn-infant is colonized with $B$. infantis, and that these bacteria are fed so as to become predominant in the gut. Fortunately, of all bacteria $B$. infantis is a major metabolizer of human milk oligosaccharides (HMOs), a major component of breast milk [147]. These complex sugars cannot be digested by our cells and are only there to feed the gut microbes. Hence, the baby needs HMO metabolism by $B$. infantis to receive nourishment from breastfeeding, and the baby needs $B$. infantis to protect against pathobionts and their dangerous metabolites. The added benefit to the baby by having pediatricians focus on this transition is that it would automatically reduce the potential exposure to TMA and, as a result, reduce the risk of later life atherosclerosis for that baby.

This is a prime example of how Microbiome First Medicine can produce immediate benefits in reducing health risks in the infant with an added longer-term benefit of preventing diseases that would emerge during adulthood. It is a completely different approach from the current trend of treating presenting symptoms and chasing after an ever-increasing number of comorbid diseases as the patient ages.

\section{Probiotics, Prebiotics and Targeted Rebiosis: Clinical and Preclinical Examples}

Significant efforts are underway both to prevent and to treat communicable diseases and NCDs by optimizing the microbiome. Installation and/or growth promotion of selected microbiota have been used to: (1) avoid the programming of disease and (2) provide critical microbial copartners necessary for the effective treatment of NCDs.

Table 4 illustrates examples from human clinical trials [131,148-183]. Not surprisingly, the best outcomes occur when there is a clear understanding of the specific microbes, genes, metabolic changes, and installation conditions that are needed to support microbiomedriven physiological benefits. But the range of benefits in human cohorts from direct management of the microbiome means that this approach can no longer be dismissed as too experimental. The era has passed in which the microbiome could simply be ignored in the practice of medicine.

Table 4. Examples of Recent Use of Probiotics/Rebiosis in Disease Prevention and Therapy.

\begin{tabular}{|c|c|c|}
\hline $\begin{array}{l}\text { Probiotic/Rebiosis Strategy } \\
\text { [Reference(s) in brackets] }\end{array}$ & $\begin{array}{l}\text { Disease Prevention/ } \\
\text { Therapy }\end{array}$ & Specific Effects \\
\hline $\begin{array}{l}\text { Bifidobacterium longum ssp infantis } \\
\text { EVC001 [131] }\end{array}$ & $\begin{array}{l}\text { Protection against pathobiont-induced } \\
\text { enteric inflammation in the infant }\end{array}$ & $\begin{array}{c}\text { Protection against enteric inflammation and reduction in } \\
\text { proinflammatory cytokine levels promoted by Clostridiaceae } \\
\text { and Enterobacteriaceae }\end{array}$ \\
\hline Multiple different probiotics [148] & $\begin{array}{l}\text { Protection against } \\
\text { antibiotic-associateddiarrhea (AAD) }\end{array}$ & $\begin{array}{l}\text { Meta-analysis of } 36 \text { studies including } 9312 \text { participants } \\
\text { showing a } 38 \% \text { reduction in disease incidence. }\end{array}$ \\
\hline Multiple probiotic regimes [149] & $\begin{array}{l}\text { Protection against post-operative adverse } \\
\text { outcomes from colon cancer surgery }\end{array}$ & $\begin{array}{l}\text { Meta analysis of six studies with } 457 \text { subjects. Probiotic } \\
\text { administration improved gut barrier and colon function, } \\
\text { reduced inflammatory markers, and increased gut } \\
\text { microbiome diversity with increased colonization } \\
\text { resistance post- surgery }\end{array}$ \\
\hline
\end{tabular}


Table 4. Cont.

\begin{tabular}{|c|c|c|}
\hline $\begin{array}{l}\text { Probiotic/Rebiosis Strategy } \\
\text { [Reference(s) in brackets] }\end{array}$ & $\begin{array}{l}\text { Disease Prevention/ } \\
\text { Therapy }\end{array}$ & Specific Effects \\
\hline $\begin{array}{l}\text { Probiotic cocktail (L. plantarum } \\
\text { MH-301, B. animalis subsp. Lactis } \\
\text { LPL-RH, L. rhamnosus LGG-18, } \\
\text { and L. acidophilus) [150] }\end{array}$ & $\begin{array}{l}\text { Protection against oral mucositis }(\mathrm{OM}) \\
\text { following nasopharyngeal cancer } \\
\text { chemoradio-therapy }\end{array}$ & $\begin{array}{c}\text { In a clinical trial of } 77 \text { patients, probiotic supplementation } \\
\text { resulted in a significantly lower prevalence of OM and a } \\
\text { reduced severity grade. }\end{array}$ \\
\hline Multiple probiotic regimes [151] & $\begin{array}{l}\text { Protection against side effects of chemo } \\
\text { and radiation cancer therapies }\end{array}$ & $\begin{array}{l}\text { Meta-analysis of } 20 \text { studies, } 17 \text { studies produced positive } \\
\text { results in reducing side effects while three studies found no } \\
\text { significant differences. }\end{array}$ \\
\hline Multiple probiotic regimes [152] & $\begin{array}{l}\text { Protection against osteoporosis in } \\
\text { post-menopausal women }\end{array}$ & $\begin{array}{l}\text { Meta analysis of five randomized controlled trials with } \\
497 \text { participants. Probiotic supplements significantly } \\
\text { increased bone mineral density in the lumbar spine. }\end{array}$ \\
\hline Multi-strain probiotic [153] & $\begin{array}{l}\text { Protection against gastrointestinal } \\
\text { symptoms among elite athletes }\end{array}$ & $\begin{array}{l}\text { Reduced gastrointestinal symptoms and distress following } \\
\text { intense training sessions competition }\end{array}$ \\
\hline $\begin{array}{l}\text { Reconstituted milk powder containing } \\
\text { the probiotic, Lactobacillus paracasei } \\
\text { SD1 [154] }\end{array}$ & $\begin{array}{l}\text { Protection against new dental caries and } \\
\text { Reduction in existing dental carieslesions }\end{array}$ & $\begin{array}{l}\text { Beneficial preventative and therapeutic oral health effects } \\
\text { in preschool children }\end{array}$ \\
\hline Multiple probiotic regimes [155] & $\begin{array}{l}\text { Protection against hospital acquired } \\
\text { Clostridioides difficile infection }\end{array}$ & $\begin{array}{c}\text { Meta-analysis of } 19 \text { prevention studies with } 6261 \text { subjects. } \\
\text { The infection rate was decreased by greater than } 50 \% \text { from } \\
\text { controls. }\end{array}$ \\
\hline Multiple probiotic regimes [156] & $\begin{array}{c}\text { Protection against Clostridioides } \\
\text { difficile-associated diarrhea in children and } \\
\text { adults }\end{array}$ & $\begin{array}{l}\text { Meta analysis with complete case analysis of } 31 \text { trials with } \\
8672 \text { participants. The risk of C. difficile infection was } \\
\text { reduced by } 60 \% \text {. }\end{array}$ \\
\hline $\begin{array}{l}\text { Oral Fecal Microbiota Transplant } \\
\text { (FMT) [157] }\end{array}$ & $\begin{array}{l}\text { Protection against recurrent } \text { Clostridioides } \\
\text { difficile infection and Long term treatment } \\
\text { of } C \text {. difficile infected patients }\end{array}$ & $\begin{array}{l}\text { Meta analysis of efficacy of oral FMT capsules. } 15 \text { studies } \\
\text { with } 753 \text { patients had an efficacy rate of } 82.1 \%\end{array}$ \\
\hline Multiple probiotic regimes [158] & $\begin{array}{l}\text { Protection against Necrotizing } \\
\text { enterocolitis (NEC) in premature infants }\end{array}$ & $\begin{array}{l}\text { Meta-analysis of } 51 \text { studies. Lactobacillus acidophilus LB was } \\
\text { the most successful of probiotics used in reducing the risk } \\
\text { of NEC }\end{array}$ \\
\hline $\begin{array}{l}\text { Different probiotic combinations } \\
\text { across the trials [159] }\end{array}$ & $\begin{array}{l}\text { Protection against complications following } \\
\text { colorectal cancer surgery }\end{array}$ & $\begin{array}{l}\text { Meta analysis of } 15 \text { trials, Improved mucosal } \\
\text { protection/function and microbial diversity following } \\
\text { antibiotics }\end{array}$ \\
\hline $\begin{array}{l}\text { Probiotic fermented dairy products } \\
\qquad[160]\end{array}$ & Protection against respiratory infections & $\begin{array}{l}\text { Meta analysis of } 22 \text { clinical trials with 10, } 290 \text { participants. } \\
\text { Overall infection rate was decreased by } 18-21 \% \text { across } \\
\text { children }(18 \%) \text {, adults }(19 \%) \text {, and elderly }(21 \%)\end{array}$ \\
\hline Microbiota transfer therapy [161-164] & Therapy for autism spectrum disorders & $\begin{array}{l}\text { Significant improvements in gastrointestinal symptoms, } \\
\text { autism functionality and gut microbiome metabolism and } \\
\text { diversity }\end{array}$ \\
\hline $\begin{array}{l}\text { Bifidobacterium breve BR03 and B632 } \\
\text { strains [165] }\end{array}$ & Therapy for obesity/insulin resistance & $\begin{array}{l}\text { Improved metabolic parameters; decreased weight; } \\
\text { improved insulin sensitivity }\end{array}$ \\
\hline Bifidobacterium longum APC1472 [166] & Therapy for obesity & Improved fasting blood glucose levels \\
\hline $\begin{array}{c}\text { Hafnia alvei probiotic strain } H A 4597^{\circledR} \\
{[167]}\end{array}$ & Therapy for obesity & $\begin{array}{l}\text { Significantly improved weight loss; feeling of fullness; } \\
\text { reduction in hip circumference; Fasting glycemia }\end{array}$ \\
\hline $\begin{array}{l}\text { Lactobacillus rhamnosus GG (LGG) } \\
\text { [168] }\end{array}$ & Therapy for coronary artery disease (CAD) & Reduced metabolic endotoxemia and mega inflammation \\
\hline Multiple probiotic regimes [169] & Therapy for type 2 diabetes & $\begin{array}{l}\text { Meta-analysis of } 26 \text { studies with } 1947 \text { participants. } \\
\text { Probiotics significantly reduced the glycemic index in type } \\
2 \text { diabetics. }\end{array}$ \\
\hline Lactobacillus paracasei HII01 [170] & Therapy for type 2 diabetes & $\begin{array}{l}\text { Decreased plasma blood glucose levels with reduced } \\
\text { inflammatory markers and restored gut microbiota profile } \\
\text { and function }\end{array}$ \\
\hline Multi-strain probiotics [171] & Therapy for type 1 diabetes (children) & Improved glycemic control \\
\hline $\begin{array}{l}\text { Multiple different synbiotics, } \\
\text { Meta-analysis [172] }\end{array}$ & Therapy for ulcerative colitis & $\begin{array}{l}\text { Beneficial reduction in inflammation; Reduced } \\
\text { inflammatory cytokines andC-reactive protein levels; } \\
\text { elevated levels of anti-inflammatory cytokines }\end{array}$ \\
\hline Fecal Microbiota Transplantation [173] & Therapy for active ulcerative colitis & $\begin{array}{c}\text { Following three treatments, increased levels of gut } \\
\text { Faecalibacterium prausnitzii bacterium and a significantly } \\
\text { reduced Mayo Clinic score for UC. }\end{array}$ \\
\hline
\end{tabular}


Table 4. Cont.

\begin{tabular}{|c|c|c|}
\hline $\begin{array}{l}\text { Probiotic/Rebiosis Strategy } \\
\text { [Reference(s) in brackets] }\end{array}$ & $\begin{array}{l}\text { Disease Prevention/ } \\
\text { Therapy }\end{array}$ & Specific Effects \\
\hline $\begin{array}{c}\text { Mix of Lactobacillus acidophilus } \\
\text { (TYCA06), Bifidobacterium longum } \\
\text { subspecies infantis (BLI-02), and } \\
\text { B. bifidum (VDD088) [174] }\end{array}$ & Therapy for chronic kidney disease & $\begin{array}{l}\text { Attenuation of renal function deterioration and reduction } \\
\qquad \text { in inflammation }\end{array}$ \\
\hline $\begin{array}{c}\text { Mixture of Lactobacilli and Bifidobacteria } \\
\text { strains [175] }\end{array}$ & Therapy for atopic dermatitis & Reduced clinical severity; reduced intestinal inflammation \\
\hline $\begin{array}{c}\text { Lactobacillus rhamnosus CGMCC } 1.3724 \\
{[176,177]}\end{array}$ & Therapy for food allergy (peanuts) & $\begin{array}{l}\text { Sustained tolerance when combined with peanut oral } \\
\text { immunotherapy }\end{array}$ \\
\hline Bifidobacterium bifidum TMC3115 [178] & Therapy for food allergy (Cow's milk) & $\begin{array}{l}\text { Probiotic treatment of infants ameliorated the allergy with } \\
\text { lower allergy scores, elevated anti-inflammatory responses, } \\
\text { lower serum IgE and higher IgG2 }\end{array}$ \\
\hline $\begin{array}{l}\text { Bifidobacterium animalis Subsp., Lactis } \\
\text { BB12 and Enterococcus faecium L3 [179] }\end{array}$ & Therapy for allergic rhinitis (AR) & $\begin{array}{l}\text { Prevention of signs and of required use of medications } \\
\text { among children. With prophylactic probiotic treatment } \\
\text { begun three months before allergy season, the signs and } \\
\text { symptoms of AR were significantly reduced as was use of } \\
\text { drugs, including oral antihistamines and local } \\
\text { corticosteroids. }\end{array}$ \\
\hline $\begin{array}{l}\text { Bifidobacterium mixture (B. longum } \\
\text { BB536, B. infantis M-63, B. breve } \\
\text { (M-16V) [180] }\end{array}$ & $\begin{array}{l}\text { Therapy for allergic rhinitis and } \\
\text { intermittent asthma }\end{array}$ & Improved symptoms and quality of life \\
\hline Multi-strain Synbiotic [181] & $\begin{array}{l}\text { Therapy for viral infections in asthmatic } \\
\text { children }\end{array}$ & Reduced number of viral infections vs. placebo group \\
\hline Lactobacillus rhamnosus SP1 [182] & Prevention of and therapy for dental caries & $\begin{array}{c}\text { Consumption of probiotic-laden milk reduced the } \\
\text { prevalence of dental caries in children }\end{array}$ \\
\hline $\begin{array}{l}\text { Lacticaseibacillus rhamnosus GG and } \\
\text { Saccharomyces cerevisiae boulardii [183] }\end{array}$ & $\begin{array}{l}\text { Used for restoration of the gut microbiome } \\
\text { following antibiotic treatment }\end{array}$ & $\begin{array}{l}\text { Increases in major bacteria groups and short chain fatty } \\
\text { acid production postantibiotics }\end{array}$ \\
\hline
\end{tabular}

Preclinical research on targeted microbiome alterations is shown in Table 5 [184-195]. The range of these studies presages where Microbiome First Medicine is headed. In particular, the power of being able to provide microbiome-initiated solutions to systems biology health problems is evident. Conversely, attempts at systems biology fixes while the microbiome remains in dysbiosis are questionable and are unlikely to produce permanent cures.

Table 5. Examples of recent preclinical trials and research with probiotics.

\begin{tabular}{ccc}
\hline $\begin{array}{c}\text { Probiotic/Rebiosis Strategy (Species) } \\
\text { [Reference(s)] }\end{array}$ & Disease Prevention/Therapy & Specific Effects \\
\hline $\begin{array}{c}\text { Faecalibacterium prausnitzii (mouse) [184] } \\
\text { Bifidobacterium longum ssp infantis } \\
\text { (mouse) [185] }\end{array}$ & Allergic asthma & $\begin{array}{c}\text { Immune cell and cytokine normalization, reduced airway } \\
\text { pathology, increase short chain fatty acid production; } \\
\text { enhance gut microbiome diversity }\end{array}$ \\
\hline $\begin{array}{c}\text { Mixed probiotics (mouse) [186] } \\
\text { Bifidobacterium longum ssp infantis } \\
\text { (mouse) [187] }\end{array}$ & Allergic asthma & $\begin{array}{c}\text { Probiotic supplementation reduced ovalbumin-specific IgE } \\
\text { antibodies, reduced infiltration by inflammatory cells, and } \\
\text { shifted cytokine levels from Th2 to Th1. }\end{array}$ \\
\hline $\begin{array}{c}\text { Lactobacillus brevis FZU0713-fermented } \\
\text { Laminaria japonica (rat) [188] }\end{array}$ & Allergic asthma & $\begin{array}{c}\text { Immune-based alleviation of allergic asthma, reduced } \\
\text { inflammation with restoration of the gut microbiome }\end{array}$ \\
\hline $\begin{array}{c}\text { Miso-derived Zygosaccharomyces sapae } \\
\text { strain I-6 -yeast (mouse) [189] }\end{array}$ & Nasal allergy & $\begin{array}{c}\text { Probiotic promotion of IL-10 producing dendritic cells that } \\
\text { suppressed the nasal allergy. }\end{array}$ \\
\hline Consortium of probiotics (mouse) [190] & Obesity & $\begin{array}{c}\text { Significantly inhibited obesity and improved serum and } \\
\text { hepatic biochemical parameters in High fat diet-fed rats. } \\
\text { Changes in both gut microbiota composition and short } \\
\text { chain fatty acid production }\end{array}$ \\
\hline
\end{tabular}


Table 5. Cont.

\begin{tabular}{|c|c|c|}
\hline $\begin{array}{l}\text { Probiotic/Rebiosis Strategy (Species) } \\
\text { [Reference(s)] }\end{array}$ & Disease Prevention/Therapy & Specific Effects \\
\hline $\begin{array}{l}\text { Lactobacillus casei adjunct therapy } \\
\text { (mouse) [191] }\end{array}$ & Malaria & Blocked parasitemia \\
\hline $\begin{array}{l}\text { Yeast-based engineered, self- tunable } \\
\text { probiotics (mouse) [192] }\end{array}$ & Inflammatory bowel disease & Reduced inflammation, intestinal fibrosis and dysbiosis \\
\hline $\begin{array}{l}\text { Lactobacillus paracasei and Lactobacillus } \\
\text { plantarum (mouse) [193] }\end{array}$ & Chronic kidney disease & $\begin{array}{l}\text { Improved kidney function with reduction in kidney injury } \\
\text { and fibrotic-related proteins and restoration of gut } \\
\text { microbiota }\end{array}$ \\
\hline $\begin{array}{c}\text { Bifidobacterium bifidum FSDJN7O5 and } \\
\text { Bifidobacterium breve FHNFQ23M3 } \\
\text { (mouse) [194] }\end{array}$ & $\begin{array}{l}\text { Diarrhea caused by enterotoxigenic } \\
\text { Escherichia coli }\end{array}$ & $\begin{array}{l}\text { Alleviation of symptoms with restoration of gut function } \\
\text { and physiology }\end{array}$ \\
\hline $\begin{array}{c}\text { Bifidobacterium bifidum G9-1 (BBG9-1) } \\
\text { (rat) [195] }\end{array}$ & $\begin{array}{l}\text { Maternal separation used as a model of } \\
\text { the colonic mucosal problems as seen } \\
\text { with irritated bowel; M1-macrophage } \\
\text { driven inflammation }\end{array}$ & $\begin{array}{c}\text { Probiotic administration protected against M1 } \\
\text { macrophage-driven adverse effects. There were reduced } \\
\text { numbers of M1 macrophages with increased CD- } 80 \\
\text { positive cells; reduced inflammatory cytokine production; } \\
\text { the probiotic administration protected and stabilized the } \\
\text { colonic mucosa }\end{array}$ \\
\hline
\end{tabular}

\section{Revisiting the Microimmunosome: Bidirectional Approaches for Homeostasis}

An important feature of the microimmunosome is bidirectional communication between the immune system and the microbiome. Bidirectional signaling operates regardless of the microbiome body location (e.g., gut, skin, airways, urogenital tract). For this reason, once systems biology units like the microimmunosome are locked into an inflammationpromoting state with likely tissue pathology, the entire systems unit needs to be rebalanced.

There are many examples in the literature where changes in the immune system can affect the human microbiome [196]. Knowing the mediators of the bidirectional immunemicrobiota cross talk can aid preventative strategies and therapeutic approaches.

The primary antibody of mucosal tissues (IgA) is a case in point when it comes to bidirectional communication and influence within the microbiome. Through reciprocal regulation, microbiota can affect, in part, IgA production by exerting control over regulatory T cells and T helper follicular cells [197,198]. In return, IgA applies selective pressures on gut microbiota. The IgA antibody promotes symbiotic bacteria cooperation within the microbiome [199-201] and selectively targets colitis-inducing gut bacteria, thereby, reducing inflammation [202,203]. Microbiota-IgA bidirectional regulation acts as a type of feedback loop [204,205].

Specialized immune cells can also affect microbiota composition. For example, subpopulations of innate lymphoid cells (ILC-1, ILC-2, and ILC-3) respond to and control different pathobionts across the human microbiomes. In the gut, ILC- 1 cells control of Salmonella typhimurium in the gut, in the stomach, ILC-2 control Helicobacter pylori. In the lungs, the ILC-3 subpopulation controls Streptococcus pneumoniae [206]. While ILC-2 is a responder to Staphylococcus aureus in the skin [207].

With bidirectional communication across the microimmunosome, it is possible to approach NCD treatments starting at either end of the systems biology unit and monitoring for effects across the microimmunosome. Treatment of metabolic syndrome is an example. Evidence suggests that both ends of the microimmunosome (the microbiota and immune cells) are useful targets. In mice, Wang et al. [208] administered a mix of fourteen composite probiotics to rebalance the microbiome. This microbiome-based treatment corrected insulin secretion, blood glucose metabolism, barrier function, and eventually immune dysfunction. Macrophage polarization was shifted from M1 polarization to M2 simply by changing the microbiome. Other investigators have had success starting at the opposite end of the microimmunosome. They treated metabolic syndrome by infusing M2 polarized macrophages into obese mice where M1 macrophages were predominant in adipose tissue. By simply rebalancing polarization of tissue macrophages, beneficial effects were seen in a reverse direction across the microimmunosome. Metabolic parameters were improved 
when the only adjustments had involved macrophages [209-211]. Recent information suggests that bile acid metabolism is a critical link that binds together gut microbiota, metabolic status, and tissue macrophage polarization to determine normal physiology vs. metabolic syndrome [212-214].

Given the bidirectional effects between the microbiome and physiological systems, it is useful to question the cause-effect relationships between physiological and/or organ toxicities and microbiome damage and/or altered metabolism. A classic example where the microbiome's role was only recently discovered is for the heavy metal lead $(\mathrm{Pb})$. Lead produces abnormal function in the neurological and immune systems with extreme vulnerability during early life $[215,216]$. $\mathrm{Pb}$ is also a timely toxicant for consideration following the disastrous mass population exposure via drinking water in Flint, Michigan [217,218].

More than a half a century of research on lead-induced immunotoxicity defined many aspects of exposure-outcomes and health risks across the life course [219-223]. But recent findings suggest that the microimmunosome may provide a better vantage point for accessing health risks and treatment options. In a review, Liu et al. [224] reported that $\mathrm{Pb}$ exposure affects all elements comprising the microimmunosome. It produces dysbiosis of gut microbiota, impairs the gut barrier and increases permeability. Pb exposure also alters bile acid metabolism and short chain fatty acid production. The researchers pointed out that $\mathrm{Pb}$-induced inflammation and immune dysregulation could result directly from $\mathrm{Pb}$ exposure or via the altered gut microbiome and loss of barrier function. They concluded that: (1) the microbiota are likely to be the first "victims" of Pb exposure and (2) probiotics appear to facilitate lead excretion and provide therapeutic benefits following Pb-induced toxicity. A second research group showed that specific $\mathrm{Pb}$-intolerant bacteria protected against internal $\mathrm{Pb}$ exposure by facilitating $\mathrm{Pb}$ excretion and reducing blood lead levels [225]. Taken together, these recent findings support the utility of the microbiome as a sentinel of problematic exposures and a biomarker of underlying health risks.

\section{Challenges for Microbiome First Medicine}

There are numerous challenges ahead for implementing a Microbiome First Medicine approach as the gold standard for human health protection and the treatment of chronic disorders. It seems clear that we have more to learn about the microbiome in the future than we know now. Almost each month new research shows us that the human microbiome is affecting and often controlling more and more aspects of our body's functions than were previously known. Gaps in knowledge exist for the human microbiome even as they exist for each of our physiological systems. But it is clear that we know enough and have already seen enough microbiome-based benefits to readjust our medical focus.

While some health care providers are already focused on the health and protection of the human microbiome, they are in the minority. Additionally, the support for their still-novel practices is dwarfed by the status quo as is reflected in pharmaceutical advertising. The formula needs to be inverted such that knowledge of and focus on the human microbiome is the medical and public health default among practitioners. It starts with an assemblage of stakeholders who fully understand that we are more than simply one species, a human mammal, and that we must be whole across the lifespan to thrive.

Those stakeholders need to include: (1) One Health educators and administrators in medical and veterinary schools, (2) leaders in public health institutions, foundations and granting agencies, (3) clinicians, and other health care service providers, (4) academic, government and industry researchers, and finally, the most important group, (5) the patients. Many microbiome-oriented groups already exist. But their information has mainly been available to those who seek it out. As stakeholders we must ensure that those who practice medicine and healthcare have the tools necessary to assess and manage the microbes of their patients.

Above all, those leaders who have advocated for personalized and precision medicine, who recognize that we cannot afford to continue growing the world's number one killer, NCDs, and who state that we need sustainable healthcare, must also embrace and help us 
protect our various microbiomes. If one examines the public health choices that occurred during the ongoing pandemic, one of the "side effects" has been human microbiome degradation, rather than restoration [226,227]. The outcomes of human microbiome degradation are well known [228] and are discussed among this and other papers in this special issue. Human microbiome degradation is not a path toward sustainable healthcare.

\section{Conclusions}

Chronic disorders such as NCDs are extensively interlinked by dysbiosis, comorbidity, and misregulated inflammation. Additionally, communicable and noncommunicable diseases and conditions are not as separate as was once thought. There are microbes that can produce NCDs under permissive conditions when microbiome dysbiosis exists and colonization resistance is compromised.

Because the human microbiome is located at the routes of exposure for many drugs, food and environmental chemicals as well as occupying sites that are the portal of entry of infectious agents, the microbiome should be the starting point for patient management. Everything else literally flows downstream (into the tissues) from these gatekeeping microbiota. They almost exclusively determine the spectrum of drug, food and environmental chemical metabolites that reach our body's internal tissues and organs, and they determine all-important biologically relevant internal doses. They are the keepers of our exposome across the lifespan. It is important that: (1) the human microbiome is protected from drugs, medical procedures, and environmental factors that result in dysbiosis of the microbiome and disease [229] and (2) support for microbiome be used to optimize the effectiveness of medical treatments [230]. For these reasons, management of a patient's microbiome is key to both disease prevention and the delivery of safe, effective levels of therapeutics to the internal body

Microbiome First Medicine starts with three basic components:

1. Knowledge of a patient's prior and current microbiome status

2. Probiotic installation in the patient to:
A. Facilitate key developmental events during infant development (e.g., micro- biota needed to digest human milk and reduce NCD-promoting inflammation)
B. Provide enhanced colonization resistance and reduced risk of infections
C. Correct a potential physiological imbalance (e.g., hormonal, immunological, neurological, G.I., hepatic, renal, or reproductive related)
D. Reduce the risk of a comorbid NCDs
E. Aid the effectiveness of a medication
F. Reduce side effects of a medication
G. Improve multi-system functionality in circumstances of neurological disorders (e.g., brain-gut)
H. Reduce the risk of cytokine storm in the event of certain infections

3. Dietary and/or prebiotic alterations to support the microbiome overall and any adjustments made to the microbiota

Funding: This research received no external funding.

Institutional Review Board Statement: Not applicable.

Informed Consent Statement: Not applicable.

Acknowledgments: The author is very grateful to Bill Cullifer, World Asthma Foundation, for the helpful discussion on asthma and to Janice Dietert for providing editorial assistance.

Conflicts of Interest: The author declares there is no conflict of interest. 


\section{References}

1. Thomas, S.; Izard, J.; Walsh, E.; Batich, K.; Chongsathidkiet, P.; Clarke, G.; Sela, D.A.; Muller, A.J.; Mullin, J.M.; Albert, K.; et al. The Host Microbiome Regulates and Maintains Human Health: A Primer and Perspective for Non-Microbiologists. Cancer Res. 2017, 77, 1783-1812. [CrossRef]

2. Mohajeri, M.H.; La Fata, G.; Steinert, R.E.; Weber, P. Relationship between the gut microbiome and brain function. Nutr. Rev. 2018, 76, 481-496. [CrossRef]

3. Fox, M.; Lee, S.M.; Wiley, K.S.; Lagishetty, V.; Sandman, C.A.; Jacobs, J.P.; Glynn, L.M. Development of the infant gut microbiome predicts temperament across the first year of life. Dev. Psychopathol. 2021, 1-12. [CrossRef]

4. Planet of the microorganisms. Nat. Rev. Microbiol. 2018, 16, 257. [CrossRef] [PubMed]

5. Spencer, S.P.; Fragiadakis, G.K.; Sonnenburg, J.L. Pursuing Human-Relevant Gut Microbiota-Immune Interactions. Immunity 2019, 51, 225-239. [CrossRef]

6. Schluter, J.; Peled, J.U.; Taylor, B.P.; Markey, K.A.; Smith, M.; Taur, Y.; Niehus, R.; Staffas, A.; Dai, A.; Fontana, E.; et al. The gut microbiota is associated with immune cell dynamics in humans. Nature 2020, 588, 303-307. [CrossRef] [PubMed]

7. Vighi, G.; Marcucci, F.; Sensi, L.; Di Cara, G.; Frati, F. Allergy and the gastrointestinal system. Clin. Exp. Immunol. 2008, 153 (Suppl. S1), 3-6. [CrossRef] [PubMed]

8. Dietert, R.R. The microbiome-immune-host defense barrier complex (microimmunosome) and developmental programming of noncommunicable diseases. Reprod. Toxicol. 2017, 68, 49-58. [CrossRef]

9. Schwierzeck, V.; Hülpüsch, C.; Reiger, M. Microbiome of Barrier Organs in Allergy: Who Runs the World? Germs! Handb. Exp. Pharmacol. 2021. [CrossRef]

10. Dixit, K.; Chaudhari, D.; Dhotre, D.; Shouche, Y.; Saroj, S. Restoration of dysbiotic human gut microbiome for homeostasis. Life Sci. 2021, 278, 119622. [CrossRef]

11. Pickard, J.M.; Zeng, M.Y.; Caruso, R.; Núñez, G. Gut microbiota: Role in pathogen colonization, immune responses, and inflammatory disease. Immunol. Rev. 2017, 279, 70-89. [CrossRef]

12. Dietert, R.R.; Dietert, J.M. Twentieth Century Dogmas Prevent Sustainable Healthcare. Am. J. Biomed. Res. Sci. 2021, 13, 409-417. Available online: https:/ /biomedgrid.com/pdf/AJBSR.MS.ID.001890.pdf (accessed on 24 July 2021).

13. Dietert, R.R. A Focus on Microbiome Completeness and Optimized Colonization Resistance in Neonatology. NeoReviews 2018, 19, e78-e88. [CrossRef]

14. Yang, X. More than 9,000,000 Unique Genes in Human Gut Bacterial Community: Estimating Gene Numbers Inside a Human Body. PLoS ONE 2009, 4, e6074. [CrossRef] [PubMed]

15. World Health Organization. Noncommunicable Diseases. 2021. Available online: https://www.who.int/news-room/fact-sheets/ detail/noncommunicable-diseases (accessed on 15 June 2021).

16. Szmyd, B.; Rogut, M.; Białasiewicz, P.; Gabryelska, A. The impact of glucocorticoids and statins on sleep quality. Sleep Med. Rev. 2021, 55, 101380. [CrossRef]

17. Sullivan, A.B.; Miller, D. Who is Taking Care of the Caregiver? J. Patient Exp. 2015, 2, 7-12. [CrossRef]

18. Montesó-Curto, P.; Cubí-Guillen, M.T.; Llàdser Navarro, A.N.; Puig Llobet, M.; Toussaint, L. Family perceptions and experiences of living with patients with fibromyalgia syndrome. Disabil. Rehabil. 2021, 7, 1-8. [CrossRef]

19. Dembic, Z. Immune system protects integrity of tissues. Mol. Immunol. 2000, 37, 563-569. [CrossRef]

20. Dietert, R.R.; Dietert, J.M. The Microbiome and Sustainable Healthcare. Healthcare 2015, 3, 100-129. [CrossRef]

21. Ogra, P.L. Respiratory syncytial virus: The virus, the disease and the immune response. Paediatr. Respir. Rev. 2004, 5, S119-S126. [CrossRef]

22. Egan, M.; Bunyavanich, S. Allergic rhinitis: The "Ghost Diagnosis" in patients with asthma. Asthma Res. Pract. 2015, 1, 8. [CrossRef] [PubMed]

23. Jacob, L.; Keil, T.; Kostev, K. Comorbid disorders associated with asthma in children in Germany-National analysis of pediatric primary care data. Pediatr. Allergy Immunol. 2016, 27, 861-866. [CrossRef] [PubMed]

24. Mirabelli, M.C.; Hsu, J.; Gower, W.A. Comorbidities of asthma in U.S. children. Respir. Med. 2016, 116, 34-40. [CrossRef] [PubMed]

25. Foong, R.X.; du Toit, G.; Fox, A.T. Asthma, Food Allergy, and How They Relate to Each Other. Front. Pediatr. 2017, 5, 89. [CrossRef] [PubMed]

26. Weatherburn, C.J.; Guthrie, B.; Mercer, S.W.; Morales, D.R. Comorbidities in adults with asthma: Population-based cross-sectional analysis of 1.4 million adults in Scotland. Clin. Exp. Allergy 2017, 47, 1246-1252. [CrossRef]

27. Ussavarungsi, K.; Limsuwat, C.; Berdine, G.; Nugent, K. Is the sinonasal questionnaire a useful screening instrument for chronic sinonasal diseases in pulmonary clinics? Chronic Respir. Dis. 2013, 10, 95-98. [CrossRef] [PubMed]

28. Tiotiu, A.; Plavec, D.; Novakova, S.; Mihaicuta, S.; Novakova, P.; Labor, M.; Bikov, A. Current opinions for the management of asthma associated with ear, nose and throat comorbidities. Eur. Respir. Rev. 2018, 27, 180056. [CrossRef]

29. Zhang, Y.; Chen, Z.; Berhane, K.; Urman, R.; Lida Chatzi, V.; Breton, C.; Gilliland, F.D. The Dynamic Relationship between Asthma and Obesity in Schoolchildren. Am. J. Epidemiol. 2020, 189, 583-591. [CrossRef] [PubMed]

30. Salsman, M.L.; Nordberg, H.O.; Wittchen, H.U.; Klotsche, J.; Mühlig, S.; Riedel, O.; Ritz, T. Extrapulmonary symptoms of patients with asthma treated in specialist pulmonary care. J. Psychosom. Res. 2021, 148, 110538. [CrossRef] 
31. Chai, P.H.; Chang, S.; Cawthorpe, D. The Temporal Hyper-Morbidity of Asthma and Attention Deficit Disorder: Implications for Interpretation Based on Comparison of Prospective and Cross-Sectional Population Samples. Psychiatry Investig. 2021, 18, 166-171. [CrossRef]

32. Havemann, B.D.; Henderson, C.A.; El-Serag, H.B. The association between gastro-oesophageal reflux disease and asthma: A systematic review. Gut 2007, 56, 1654-1664. [CrossRef] [PubMed]

33. Koo, H.K.; Song, P.; Lee, J.H. Novel association between asthma and osteoarthritis: A nationwide health and nutrition examination survey. BMC Pulm. Med. 2021, 21, 59. [CrossRef]

34. Fretzayas, A.; Moustaki, M.; Loukou, I.; Douros, K. Differentiating vocal cord dysfunction from asthma. Asthma Allergy 2017, 10, 277-283. [CrossRef] [PubMed]

35. Sweeney, J.; Patterson, C.C.; Menzies-Gow, A.; Niven, R.M.; Mansur, A.H.; Bucknall, C.; Chaudhuri, R.; Price, D.; Brightling, C.E.; Heaney, L.G.; et al. Comorbidity in severe asthma requiring systemic corticosteroid therapy: Cross-sectional data from the Optimum Patient Care Research Database and the British Thoracic Difficult Asthma Registry. Thorax 2016, 71, 339-346. [CrossRef] [PubMed]

36. Chan, R.; Lipworth, B. Impact of nasal polyps on endotype and phenotype in patients with moderate to severe asthma. Ann. Allergy Asthma Immunol. 2021, 18, S1081-S1206. [CrossRef]

37. Landré, B.; Nadif, R.; Goldberg, M.; Gourmelen, J.; Zins, M.; Ankri, J.; Herr, M. Asthma is associated with frailty among community-dwelling adults: The GAZEL cohort. BMJ Open Respir. Res. 2020, 7, e000526. [CrossRef] [PubMed]

38. Zolotareva, O.; Saik, O.V.; Königs, C.; Bragina, E.Y.; Goncharova, I.A.; Freidin, M.B.; Dosenko, V.E.; Ivanisenko, V.A.; Hofestädt, R. Comorbidity of asthma and hypertension may be mediated by shared genetic dysregulation and drug side effects. Sci. Rep. 2019, 9, 16302. [CrossRef]

39. Qaisar, R.; Qayum, M.; Muhammad, T. Reduced sarcoplasmic reticulum $\mathrm{Ca}^{2+}$ ATPase activity underlies skeletal muscle wasting in asthma. Life Sci. 2021, 273, 119296. [CrossRef]

40. Lyons, J.J.; Yi, T. Mast cell tryptases in allergic inflammation and immediate hypersensitivity. Curr. Opin. Immunol. 2021, 72, 94-106. [CrossRef]

41. Keselman, A.; Heller, N. Estrogen Signaling Modulates Allergic Inflammation and Contributes to Sex Differences in Asthma. Front. Immunol. 2015, 6, 568. [CrossRef]

42. Tesse, R.; Schieck, M.; Kabesch, M. Asthma and endocrine disorders: Shared mechanisms and genetic pleiotropy. Mol. Cell. Endocrinol. 2011, 333, 103-111. [CrossRef]

43. Mueller, N.T.; Koh, W.P.; Odegaard, A.O.; Gross, M.D.; Yuan, J.M.; Pereira, M.A. Asthma and the risk of type 2 diabetes in the Singapore Chinese Health Study. Diabetes Res. Clin. Pract. 2013, 99, 192-199. [CrossRef] [PubMed]

44. Dixit, R. Asthma and obstructive sleep apnea: More than an association! Lung India 2018, 35, 191-192. [CrossRef] [PubMed]

45. Kavanagh, J.; Jackson, D.J.; Kent, B.D. Sleep and asthma. Curr. Opin. Pulm. Med. 2018, 24, 569-573. [CrossRef] [PubMed]

46. Luyster, F.S.; Ritterband, L.M.; Sereika, S.M.; Buysse, D.J.; Wenzel, S.E.; Strollo, P.J. Internet-Based Cognitive-Behavioral Therapy for Insomnia in Adults With Asthma: A Pilot Study. Behav. Sleep Med. 2020, 18, 10-22. [CrossRef]

47. Wee, J.H.; Park, M.W.; Min, C.; Byun, S.H.; Park, B.; Choi, H.G. Association between asthma and cardiovascular disease. Eur. J. Clin. Investig. 2021, 51, e13396. [CrossRef]

48. Page, L.K.; Staples, K.J.; Spalluto, C.M.; Watson, A.; Wilkinson, T.M.A. Influence of Hypoxia on the Epithelial-Pathogen Interactions in the Lung: Implications for Respiratory Disease. Front. Immunol. 2021, 12, 653969. [CrossRef]

49. Corlateanu, A.; Stratan, I.; Covantev, S.; Botnaru, V.; Corlateanu, O.; Siafakas, N. Asthma and stroke: A narrative review. Asthma Res. Pract. 2021, 7, 3. [CrossRef]

50. Raita, Y.; Camargo, C.A., Jr.; Faridi, M.K.; Brown, D.F.M.; Shimada, Y.J.; Hasegawa, K. Risk of Acute Myocardial Infarction and Ischemic Stroke in Patients with Asthma Exacerbation: A Population-Based, Self-Controlled Case Series Study. J. Allergy Clin. Immunol. Pract. 2020, 8, 188-194.e8. [CrossRef]

51. Johnson, E.; McAlees, J.; Lewkowich, I.; Sah, R. Asthma and Posttraumatic Stress Disorder (PTSD): Emerging links, potential models and mechanisms. Brain Behav. Immun. 2021, 6, S0889-S1591. [CrossRef]

52. Yingchoncharoen, P.; Charoenngam, N.; Ponvilawan, B.; Thongpiya, J.; Chaikijurajai, T.; Ungprasert, P. The Association between Asthma and Risk of Myasthenia Gravis: A Systematic Review and Meta-analysis. Lung 2021, 199, 273-280. [CrossRef]

53. Charokopos, A.; Braman, S.S.; Brown, S.A.W.; Mhango, G.; de-Torres, J.P.; Zulueta, J.J.; Sharma, S.; Holguin, F.; Sigel, K.M.; Powell, C.A.; et al. Lung Cancer Risk Among Patients with Asthma-Chronic Obstructive Pulmonary Disease Overlap. Ann. Am. Thorac. Soc. 2021. [CrossRef]

54. Pashley, C.H.; Wardlaw, A.J. Allergic fungal airways disease (AFAD): An under-recognised asthma endotype. Mycopathologia 2021. [CrossRef]

55. Sgrazzutti, L.; Sansone, F.; Attanasi, M.; Di Pillo, S.; Chiarelli, F. Coaggregation of Asthma and Type 1 Diabetes in Children: A Narrative Review. Int. J. Mol. Sci. 2021, 22, 5757. [CrossRef]

56. Bekaert, S.; Rocks, N.; Vanwinge, C.; Noel, A.; Cataldo, D. Asthma-related inflammation promotes lung metastasis of breast cancer cells through CCL11-CCR3 pathway. Respir. Res. 2021, 22, 61. [CrossRef]

57. Berti, A.; Cornec, D.; Casal Moura, M.; Smyth, R.J.; Dagna, L.; Specks, U.; Keogh, K.A. Eosinophilic Granulomatosis with Polyangiitis: Clinical Predictors of Long-term Asthma Severity. Chest 2020, 157, 1086-1099. [CrossRef] 
58. Wang, L.; Gao, S.; Yu, M.; Sheng, Z.; Tan, W. Association of asthma with coronary heart disease: A meta analysis of 11 trials. PLoS ONE 2017, 12, e0179335. [CrossRef] [PubMed]

59. Tang, H.; Lang, A.; Teo, S.M.; Judd, L.M.; Gangnon, R.; Evans, M.D.; Lee, K.E.; Vrtis, R.; Holt, P.G.; Lemanske, R.F.; et al. Developmental patterns in the nasopharyngeal microbiome during infancy are associated with asthma risk. J. Allergy Clin. Immunol. 2021, 147, 1683-1691. [CrossRef]

60. Lee, D.C.; Kananurak, A.; Tran, M.T.; Connolly, P.A.; Polage, C.R.; Iwase, T.; Bevins, C.L.; Underwood, M.A. Bacterial Colonization of the Hospitalized Newborn: Competition between Staphylococcus aureus and Staphylococcus epidermidis. Pediatr. Infect. Dis. J. 2019, 38, 682-686. [CrossRef]

61. Cole, A.L.; Sundar, M.; Lopez, A.; Forsman, A.; Yooseph, S.; Cole, A.M. Identification of Nasal Gammaproteobacteria with Potent Activity against Staphylococcus aureus: Novel Insights into the "Noncarrier" State. mSphere 2021, 6, e01015-e01020. [CrossRef]

62. Dietert, R. The Human Superorganism: How the Microbiome Is Revolutionizing the Pursuit of a Healthy Life, 1st ed.; Dutton Penguin Random House: New York, NY, USA, 2016; pp. 122-127.

63. Ribeiro, J.C.; Duarte, J.G.; Gomes, G.A.O.; Costa-Guarisco, L.P.; de Jesus, I.T.M.; Nascimento, C.M.C.; Santos-Orlandi, A.A.; Orlandi, F.S.; Vasilceac, F.A.; Zazzetta, M.S.; et al. Associations between inflammatory markers and muscle strength in older adults according to the presence or absence of obesity. Exp. Gerontol. 2021, 151, 111409. [CrossRef]

64. Abbasi, A.; Juszczyk, D.; van Jaarsveld, C.H.M.; Gulliford, M.C. Body Mass Index and Incident Type 1 and Type 2 Diabetes in Children and Young Adults: A Retrospective Cohort Study. J. Endocr. Soc. 2017, 1, 524-537. [CrossRef] [PubMed]

65. Hall, J.E.; Mouton, A.J.; da Silva, A.A.; Omoto, A.C.M.; Wang, Z.; Li, X.; do Carmo, J.M. Obesity, kidney dysfunction, and inflammation: Interactions in hypertension. Cardiovasc. Res. 2021, 117, 1859-1876. [CrossRef]

66. Jahangir, E.; De Schutter, A.; Lavie, C.J. The relationship between obesity and coronary artery disease. Transl. Res. 2014, 164, 336-344. [CrossRef]

67. Rychter, A.M.; Naskręt, D.; Zawada, A.; Ratajczak, A.E.; Dobrowolska, A.; Krela-Kaźmierczak, I. Can We Change in Diet and Behaviour in Order to Decrease Carotid Intima-Media Thickness in Patients with Obesity? J. Personal. Med. 2021, 11, 505. [CrossRef]

68. Moore, J.M.; Waldrop, S.W.; Cree-Green, M. Weight Management in Adolescents with Polycystic Ovary Syndrome. Curr. Obes. Rep. 2021. [CrossRef] [PubMed]

69. Osborn, D.J.; Strain, M.; Gomelsky, A.; Rothschild, J.; Dmochowski, R. Obesity and female stress urinary incontinence. Urology 2013, 82, 759-763. [CrossRef] [PubMed]

70. King, L.K.; March, L.; Anandacoomarasamy, A. Obesity \& osteoarthritis. Indian J. Med. Res. 2013, 138, $185-193$.

71. Klop, B.; Elte, J.W.; Cabezas, M.C. Dyslipidemia in obesity: Mechanisms and potential targets. Nutrients 2013, 5, 1218-1240. [CrossRef] [PubMed]

72. Jehan, S.; Zizi, F.; Pandi-Perumal, S.R.; Wall, S.; Auguste, E.; Myers, A.K.; Jean-Louis, G.; McFarlane, S.I. Obstructive Sleep Apnea and Obesity: Implications for Public Health. Sleep Med. Dis. 2017, 1, 00019.

73. Zhao, B.; Sun, S.; He, X.; Yang, J.; Ma, X.; Yan, B. Sleep fragmentation and the risk of obesity: The Sleep Heart Health Study. Obesity 2021, 29, 1387-1393. [CrossRef]

74. Polyzos, S.A.; Kountouras, J.; Mantzoros, C.S. Obesity and nonalcoholic fatty liver disease: From pathophysiology to therapeutics. Metabolism 2019, 92, 82-97. [CrossRef]

75. Festi, D.; Colecchia, A.; Sacco, T.; Bondi, M.; Roda, E.; Marchesini, G. Hepatic steatosis in obese patients: Clinical aspects and prognostic significance. Obes. Rev. 2004, 5, 27-42. [CrossRef]

76. Jiang, D.; Wang, L.; Bai, C.; Chen, O. Association between abdominal obesity and asthma: A meta-analysis. Allergy Asthma Clin. Immunol. 2019, 15, 16. [CrossRef]

77. Zhang, Y.; Johansson, L.; Andersson-Assarsson, J.; Taube, M.; Peltonen, M.; Svensson, P.A.; Herder, C.; Rudin, A.; Carlsson, L.; Rantapää-Dahlqvist, S.; et al. Adiponectin Associates with Rheumatoid Arthritis Risk in Overweight and Obesity Independently of Other Adipokines. J. Clin. Med. 2021, 10, 2791. [CrossRef]

78. Mendall, M.; Harpsøe, M.C.; Kumar, D.; Andersson, M.; Jess, T. Relation of body mass index to risk of developing inflammatory bowel disease amongst women in the Danish National Birth Cohort. PLoS ONE 2018, 13, e0190600. [CrossRef]

79. Yang, J.R.; Hidayat, K.; Chen, C.L.; Li, Y.H.; Xu, J.Y.; Qin, L.Q. Body mass index, waist circumference, and risk of hearing loss: A meta-analysis and systematic review of observational study. Environ. Health Prev. Med. 2020, 25, 25. [CrossRef]

80. Blokhin, I.O.; Lentz, S.R. Mechanisms of thrombosis in obesity. Curr. Opin. Hematol. 2013, 20, 437-444. [CrossRef]

81. Dağ, Z.Ö.; Dilbaz, B. Impact of obesity on infertility in women. J. Turk. Ger. Gynecol. Assoc. 2015, 16, 111-117. [CrossRef]

82. Crow, R.S.; Lohman, M.C.; Titus, A.J.; Cook, S.B.; Bruce, M.L.; Mackenzie, T.A.; Bartels, S.J.; Batsis, J.A. Association of Obesity and Frailty in Older Adults: NHANES 1999-2004. J. Nutr. Health Aging 2019, 23, 138-144. [CrossRef]

83. Lloret, A.; Monllor, P.; Esteve, D.; Cervera-Ferri, A.; Lloret, M.A. Obesity as a Risk Factor for Alzheimer's Disease: Implication of Leptin and Glutamate. Front. Neurosci. 2019, 13, 508. [CrossRef]

84. Lee, J.; Lee, J.Y.; Lee, J.H.; Jung, S.M.; Suh, Y.S.; Koh, J.H.; Kwok, S.K.; Ju, J.H.; Park, K.S.; Park, S.H. Visceral fat obesity is highly associated with primary gout in a metabolically obese but normal weighted population: A case control study. Arthritis Res. Ther. 2015, 17, 79. [CrossRef]

85. Song, R.H.; Wang, B.; Yao, Q.M.; Li, Q.; Jia, X.; Zhang, J.A. The Impact of Obesity on Thyroid Autoimmunity and Dysfunction: A Systematic Review and Meta-Analysis. Front. Immunol. 2019, 10, 2349. [CrossRef] 
86. Ma, Y.; Ajnakina, O.; Steptoe, A.; Cadar, D. Higher risk of dementia in English older individuals who are overweight or obese. Int. J. Epidemiol. 2020, 49, 1353-1365. [CrossRef]

87. Schreiner, T.G.; Genes, T.M. Obesity and Multiple Sclerosis-A Multifaceted Association. J. Clin. Med. 2021, 10, 2689. [CrossRef]

88. McWhinney, S.; Kolenic, M.; Franke, K.; Fialova, M.; Knytl, P.; Matejka, M.; Spaniel, F.; Hajek, T. Obesity as a Risk Factor for Accelerated Brain Ageing in First-Episode Psychosis-A Longitudinal Study. Schizophr. Bull. 2021. [CrossRef]

89. Ramos-Nino, M.E.; MacLean, C.D.; Littenberg, B. Association between prevalence of obstructive lung disease and obesity: Results from The Vermont Diabetes Information System. Asthma Res. Pract. 2021, 7, 6. [CrossRef]

90. Opel, N.; Narr, K.L.; Abbott, C.; Argyelan, M.; Espinoza, R.; Emsell, L.; Bouckaert, F.; Sienaert, P.; Vandenbulcke, M.; Nordanskog, P.; et al. Elevated body weight modulates subcortical volume change and associated clinical response following electroconvulsive therapy. J. Psychiatry Neurosci. 2021, 46, E418-E426. [CrossRef]

91. Vander Velden, J.W.; Osborne, D.M. Obesity Prevents S-Adenosylmethionine-Mediated Improvements in Age-Related Peripheral and Hippocampal Outcomes. Nutrients 2021, 13, 1201. [CrossRef]

92. Norden, A.; Rekhtman, S.; Strunk, A.; Garg, A. Risk of psoriasis according to body mass index: A retrospective cohort analysis. J. Am. Acad. Dermatol. 2021, 9, S0190-S9622. [CrossRef]

93. Fast, K.; Björk, A.; Strandberg, M.; Johannesson, E.; Wentz, E.; Dahlgren, J. Half of the children with overweight or obesity and attention-deficit/hyperactivity disorder reach normal weight with stimulants. Acta Paediatr. 2021. [CrossRef]

94. Stenvinkel, P.; Zoccali, C.; Ikizler, T.A. Obesity in CKD-What should nephrologists know? J. Am. Soc. Nephrol. 2013, 24, 1727-1736. [CrossRef]

95. Bhaskaran, K.; Douglas, I.; Forbes, H.; dos-Santos-Silva, I.; Leon, D.A.; Smeeth, L. Body-mass index and risk of 22 specific cancers: A population-based cohort study of $5 \cdot 24$ million UK adults. Lancet 2014, 384, 755-765. [CrossRef]

96. Nussbaum, B.M.; Mathew, M.S.; Atem, F.; Barlow, S.E.; Gupta, O.T.; Messiah, S.E. Distribution of comorbidities as primary diagnoses by obesity class among patients in a large US paediatric healthcare system. Clin. Obes. 2021, e12478. [CrossRef]

97. Martin-Taboada, M.; Vila-Bedmar, R.; Medina-Gómez, G. From Obesity to Chronic Kidney Disease: How Can Adipose Tissue Affect Renal Function? Nephron 2021, 21, 1-5. [CrossRef]

98. Yuan, L.; Chang, M.; Wang, J. Abdominal obesity, body mass index and the risk of frailty in community-dwelling older adults: A systematic review and meta-analysis. Age Ageing 2021, 50, 1118-1128. [CrossRef]

99. Paccoud, R.; Saint-Laurent, C.; Piccolo, E.; Tajan, M.; Dortignac, A.; Pereira, O.; Le Gonidec, S.; Baba, I.; Gélineau, A.; Askia, H.; et al. SHP2 drives inflammation-triggered insulin resistance by reshaping tissue macrophage populations. Sci. Transl. Med. 2021, 13, eabe2587. [CrossRef]

100. Connolly, K.D.; Rees, D.A.; James, P.E. Role of adipocyte-derived extracellular vesicles in vascular inflammation. Free Radic. Biol. Med. 2021, M172, 58-64. [CrossRef]

101. Dietert, R.R.; DeWitt, J.C.; Germolec, D.R.; \& Zelikoff, J.T. Breaking patterns of environmentally influenced disease for health risk reduction: Immune perspectives. Environ. Health Perspect. 2010, 118, 1091-1099. [CrossRef]

102. Halling, M.L.; Kjeldsen, J.; Knudsen, T.; Nielsen, J.; Hansen, L.K. Patients with inflammatory bowel disease have increased risk of autoimmune and inflammatory diseases. World J. Gastroenterol. 2017, 23, 6137-6146. [CrossRef]

103. Butwicka, A.; Olén, O.; Larsson, H.; Halfvarson, J.; Almqvist, C.; Lichtenstein, P.; Serlachius, E.; Frisén, L.; Ludvigsson, J.F. Association of Childhood-Onset Inflammatory Bowel Disease with Risk of Psychiatric Disorders and Suicide Attempt. JAMA Pediatr. 2019, 173, 969-978. [CrossRef]

104. Takeshita, J.; Grewal, S.; Langan, S.M.; Mehta, N.N.; Ogdie, A.; Van Voorhees, A.S.; Gelfand, J.M. Psoriasis and comorbid diseases: Epidemiology. J. Am. Acad. Dermatol. 2017, 76, 377-390. [CrossRef] [PubMed]

105. King, D.E.; Xiang, J.; Pilkerton, C.S. Multimorbidity Trends in United States Adults, 1988-2014. J. Am. Board Fam. Med. JABFM 2018, 31, 503-513. [CrossRef]

106. Aljeaidi, M.S.; Tan, E.C. The association between polypharmacy and cognitive ability in older adults: A national cohort study. Res. Soc. Adm. Pharm. 2021, 5, S1551-S7411. [CrossRef]

107. Dietert, R.R.; Silbergeld, E.K. Biomarkers for the 21st century: Listening to the microbiome. Toxicol. Sci. 2015, 144, 208-216. [CrossRef]

108. Saha, J.R.; Butler, V.P., Jr.; Neu, H.C.; Lindenbaum, J. Digoxin-inactivating bacteria: Identification in human gut flora. Science 1983, 220, 325-327. [CrossRef]

109. Tuteja, S.; Ferguson, J.F. Gut Microbiome and Response to Cardiovascular Drugs. Circ. Genomic Prec. Med. 2019, 12, 421-429. [CrossRef] [PubMed]

110. Haiser, H.J.; Seim, K.L.; Balskus, E.P.; Turnbaugh, P.J. Mechanistic insight into digoxin inactivation by Eggerthella lenta augments our understanding of its pharmacokinetics. Gut Microbes 2014, 5, 233-238. [CrossRef] [PubMed]

111. Rogers, M.; Aronoff, D.M. The influence of non-steroidal anti-inflammatory drugs on the gut microbiome. Clin. Microbiol. Infect. 2016, 22, 178.e1-178.e9. [CrossRef]

112. Vich Vila, A.; Collij, V.; Sanna, S.; Sinha, T.; Imhann, F.; Bourgonje, A.R.; Mujagic, Z.; Jonkers, D.M.A.E.; Masclee, A.A.M.; Fu, J.; et al. Impact of commonly used drugs on the composition and metabolic function of the gut microbiota. Nat. Commun. 2020, 11, 362. [CrossRef]

113. Rekatsina, M.; Paladini, A.; Cifone, M.G.; Lombardi, F.; Pergolizzi, J.V.; Varrassi, G. Influence of Microbiota on NSAID Enteropathy: A Systematic Review of Current Knowledge and the Role of Probiotics. Adv. Ther. 2020, 37, 1933-1945. [CrossRef] 
114. Imhann, F.; Bonder, M.J.; Vich Vila, A.; Fu, J.; Mujagic, Z.; Vork, L.; Tigchelaar, E.F.; Jankipersadsing, S.A.; Cenit, M.C.; Harmsen, H.J.; et al. Proton pump inhibitors affect the gut microbiome. Gut 2016, 65, 740-748. [CrossRef] [PubMed]

115. Imhann, F.; Vich Vila, A.; Bonder, M.J.; Lopez Manosalva, A.G.; Koonen, D.P.Y.; Fu, J.; Wijmenga, C.; Zhernakova, A.; Weersma, R.K. The influence of proton pump inhibitors and other commonly used medication on the gut microbiota. Gut Microbes 2017, 8 , 351-358. [CrossRef]

116. Lukić, I.; Getselter, D.; Ziv, O.; Oron, O.; Reuveni, E.; Koren, O. Elliott, E. Antidepressants affect gut microbiota and Ruminococcus flavefaciens is able to abolish their effects on depressive-like behavior. Transl. Psychiatry 2019, 9, 133. [CrossRef]

117. Sjöstedt, P.; Jesper Enander, J.; Isung, J. Serotonin Reuptake Inhibitors and the Gut Microbiome: Significance of the Gut Microbiome in Relation to Mechanism of Action, Treatment Response, Side Effects, and Tachyphylaxis. Front. Psychiatry 2021, 12, 778. [CrossRef]

118. Weersma, R.K.; Zhernakova, A.; Fu, J. Interaction between drugs and the gut microbiome. Gut 2020, 69, 1510-1519. [CrossRef]

119. Tropini, C.; Moss, E.L.; Merrill, B.D.; Ng, K.M.; Higginbottom, S.K.; Casavant, E.P.; Gonzalez, C.G.; Fremin, B.; Bouley, D.M.; Elias, J.E.; et al. Transient Osmotic Perturbation Causes Long-Term Alteration to the Gut Microbiota. Cell 2018, 173, 1742-1754.e17. [CrossRef]

120. Pequegnat, B.; Monteiro, M.A. Carbohydrate Scaffolds for the Study of the Autism-associated Bacterium, Clostridium bolteae. Curr. Med. Chem. 2019, 26, 6341-6348. [CrossRef]

121. Duranti, S.; Ruiz, L.; Lugli, G.A.; Tames, H.; Milani, C.; Mancabelli, L.; Mancino, W.; Longhi, G.; Carnevali, L.; Sgoifo, A.; et al. Bifidobacterium adolescentis as a key member of the human gut microbiota in the production of GABA. Sci. Rep. 2020, 10, 14112. [CrossRef]

122. Eitan, S.; Madison, C.A.; Kuempel, J. The self-serving benefits of being a good host: A role for our micro-inhabitants in shaping opioids' function. Neurosci. Biobehav. Rev. 2021, 127, 284-295. [CrossRef]

123. O'Sullivan, S.J.; Schwaber, J.S. Similarities in alcohol and opioid withdrawal syndromes suggest common negative reinforcement mechanisms involving the interoceptive antireward pathway. Neurosci. Biobehav. Rev. 2021, 125, 355-364. [CrossRef]

124. Goubet, A.-G.; Daillère, R.; Routy, B.; Derosa, L.M.; Roberti, P.; Zitvogel, L. The impact of the intestinal microbiota in therapeutic responses against cancer. C. R. Biol. 2018, 341, 284-289. [CrossRef] [PubMed]

125. Hally, A.; Leonetti, A.; Gregori, A.; Tiseo, M.; Deng, D.M.; Giovannetti, E.; Peters, G.J. The Role of the Microbiome in Cancer and Therapy Efficacy: Focus on Lung Cancer. Anticancer Res. 2020, 40, 4807-4818. [CrossRef] [PubMed]

126. Haiser, H.J.; Gootenberg, D.B.; Chatman, K.; Sirasani, G.; Balskus, E.P.; Turnbaugh, P.J. Predicting and manipulating cardiac drug inactivation by the human gut bacterium Eggerthella lenta. Science 2013, 341, 295-298. [CrossRef]

127. Maseda, D.; Zackular, J.P.; Trindade, B.; Kirk, L.; Roxas, J.L.; Rogers, L.M.; Washington, M.K.; Du, L.; Koyama, T.; Viswanathan, V.K.; et al. Nonsteroidal Anti-inflammatory Drugs Alter the Microbiota and Exacerbate Clostridium difficile Colitis while Dysregulating the Inflammatory Response. mBio 2019, 10, e02282-e18. [CrossRef] [PubMed]

128. Bruno, G.; Zaccari, P.; Rocco, G.; Scalese, G.; Panetta, C.; Porowska, B.; Pontone, S.; Severi, C. Proton pump inhibitors and dysbiosis: Current knowledge and aspects to be clarified. World J. Gastroenterol. 2019, 25, 2706-2719. [CrossRef]

129. Le Bastard, Q.; Berthelot, L.; Soulillou, J.P.; Montassier, E. Impact of non-antibiotic drugs on the human intestinal microbiome. Expert Rev. Mol. Diagn. 2021, 15, 1-14. [CrossRef]

130. Baltz, R.H. Genome mining for drug discovery: Progress at the front end. J. Ind. Microbiol. Biotechnol. 2021. [CrossRef]

131. Henrick, B.M.; Chew, S.; Casaburi, G.; Brown, H.K.; Frese, S.A.; Zhou, Y.; Underwood, M.A.; Smilowitz, J.T. Colonization by B. infantis EVC001 modulates enteric inflammation in exclusively breastfed infants. Pediatr. Res. 2019, 86, 749-757. [CrossRef]

132. Henrick, B.M.; Rodriguez, L.; Lakshmikanth, T.; Pou, C.; Henckel, E.; Arzoomand, A.; Olin, A.; Wang, J.; Mikes, J.; Tan, Z.; et al. Bifidobacteria-mediated immune system imprinting early in life. Cell 2021, 184, 3884-3898. [CrossRef]

133. Ottman, N.; Reunanen, J.; Meijerink, M.; Pietilä, T.E.; Kainulainen, V.; Klievink, J.; Huuskonen, L.; Aalvink, S.; Skurnik, M.; Boeren, S.; et al. Pili-like proteins of Akkermansia muciniphila modulate host immune responses and gut barrier function. PLoS ONE 2017, 12, e0173004. [CrossRef]

134. Finlay, B.B.; CIFAR Humans; Microbiome. Are noncommunicable diseases communicable? Science 2020, 367, 250-251. [CrossRef]

135. Dietert, R.R. Lessons for Human Holobiont Medicine in the Era of SARS-Cov-2. Am. J. Biomed. Res. Sci. 2021, 13, 152-156.

136. Teufelberger, A.R.; Bröker, B.M.; Krysko, D.V.; Bachert, C.; Krysko, O. Staphylococcus aureus Orchestrates Type 2 Airway Diseases. Trends Mol. Med. 2019, 25, 696-707. [CrossRef]

137. Baldelli, V.; Scaldaferri, F.; Putignani, L.; Del Chierico, F. The Role of Enterobacteriaceae in Gut Microbiota Dysbiosis in Inflammatory Bowel Diseases. Microorganisms 2021, 9, 697. [CrossRef] [PubMed]

138. Rath, S.; Rud, T.; Karch, A.; Pieper, D.H.; Vital, M. Pathogenic functions of host microbiota. Microbiome 2018, 6, 174. [CrossRef] [PubMed]

139. Rath, S.; Rud, T.; Pieper, D.H.; Vital, M. Potential TMA-Producing Bacteria Are Ubiquitously Found in Mammalia. Front. Microbiol. 2020, 10, 2966. [CrossRef]

140. Dalla Via, A.; Gargari, G.; Taverniti, V.; Rondini, G.; Velardi, I.; Gambaro, V.; Visconti, G.L.; De Vitis, V.; Gardana, C.; Ragg, E.; et al. Urinary TMAO Levels Are Associated with the Taxonomic Composition of the Gut Microbiota and with the Choline TMA-Lyase Gene (cutC) Harbored by Enterobacteriaceae. Nutrients 2019, 12, 62. [CrossRef] 
141. Dietert, R.R.; Etzel, R.A.; Chen, D.; Halonen, M.; Holladay, S.D.; Jarabek, A.M.; Landreth, K.; Peden, D.B.; Pinkerton, K.; Smialowicz, R.J.; et al. Workshop to identify critical windows of exposure for children's health: Immune and respiratory systems work group summary. Environ. Health Perspect. 2000, 108, 483-490. [CrossRef]

142. Heindel, J.J. The developmental basis of disease: Update on environmental exposures and animal models. Basic Clin. Pharmacol. Toxicol. 2019, 125, 5-13. [CrossRef]

143. Barker, D.J. The fetal and infant origins of adult disease. BMJ Br. Med. J. 1990, 301, 1111. [CrossRef] [PubMed]

144. Heindel, J.J.; Vandenberg, L.N. Developmental origins of health and disease: A paradigm for understanding disease cause and prevention. Curr. Opin. Pediatr. 2015, 27, 248-253. [CrossRef]

145. Milani, C.; Duranti, S.; Bottacini, F.; Casey, E.; Turroni, F.; Mahony, J.; Belzer, C.; Delgado Palacio, S.; Arboleya Montes, S.; Mancabelli, L.; et al. The First Microbial Colonizers of the Human Gut: Composition, Activities, and Health Implications of the Infant Gut Microbiota. Microbiol. Mol. Biol. Rev. MMBR 2017, 81, e00036-17. [CrossRef] [PubMed]

146. Nguyen, M.; Holdbrooks, H.; Mishra, P.; Abrantes, M.A.; Eskew, S.; Garma, M.; Oca, C.G.; McGuckin, C.; Hein, C.B.; Mitchell, R.D.; et al. Impact of Probiotic, B. infantis EVC001 Feeding in Premature Infants on the Gut Microbiome, Nosocomially Acquired Antibiotic Resistance, and Enteric Inflammation. Front. Pediat. 2021, 9, 618009. [CrossRef]

147. Duar, R.M.; Henrick, B.M.; Casaburi, G.; Frese, S.A. Integrating the Ecosystem Services Framework to Define Dysbiosis of the Breastfed Infant Gut: The Role of B. infantis and Human Milk Oligosaccharides. Front. Nutr. 2020, 7, 33. [CrossRef]

148. Liao, W.; Chen, C.; Wen, T.; Zhao, Q. Probiotics for the Prevention of Antibiotic-associated Diarrhea in Adults: A Meta-Analysis of Randomized Placebo-Controlled Trials. J. Clin. Gastroenterol. 2021, 55, 469-480. [CrossRef]

149. Wierzbicka, A.; Mańkowska-Wierzbicka, D.; Mardas, M.; Stelmach-Mardas, M. Role of Probiotics in Modulating Human Gut Microbiota Populations and Activities in Patients with Colorectal Cancer-A Systematic Review of Clinical Trials. Nutrients 2021, 13, 1160. [CrossRef]

150. Xia, C.; Jiang, C.; Li, W.; Wei, J.; Hong, H.; Li, J.; Feng, L.; Wei, H.; Xin, H.; Chen, T. A Phase II Randomized Clinical Trial and Mechanistic Studies Using Improved Probiotics to Prevent Oral Mucositis Induced by Concurrent Radiotherapy and Chemotherapy in Nasopharyngeal Carcinoma. Front. Immunol. 2021, 12, 618150. [CrossRef]

151. Rodriguez-Arrastia, M.; Martinez-Ortigosa, A.; Rueda-Ruzafa, L.; Folch Ayora, A.; Ropero-Padilla, C. Probiotic Supplements on Oncology Patients' Treatment-Related Side Effects: A Systematic Review of Randomized Controlled Trials. Int. J. Environ. Res. Public Health 2021, 18, 4265. [CrossRef]

152. Yu, J.; Cao, G.; Yuan, S.; Luo, C.; Yu, J.; Cai, M. Probiotic supplements and bone health in postmenopausal women: A meta-analysis of randomised controlled trials. BMJ Open 2021, 11, e041393. [CrossRef]

153. Schreiber, C.; Tamir, S.; Golan, R.; Weinstein, A.; Weinstein, Y. The effect of probiotic supplementation on performance, inflammatory markers and gastro-intestinal symptoms in elite road cyclists. J. Int. Soc. Sports Nutr. 2021, 18, 36. [CrossRef]

154. Piwat, S.; Teanpaisan, R.; Manmontri, C.; Wattanarat, O.; Pahumunto, N.; Makeudom, A.; Krisanaprakornkit, S.; Nirunsittirat, A. Efficacy of Probiotic Milk for Caries Regression in Preschool Children: A Multicenter Randomized Controlled Trial. Caries Res. 2020, 54, 491-501. [CrossRef]

155. Shen, N.T.; Maw, A.; Tmanova, L.L.; Pino, A.; Ancy, K.; Crawford, C.V.; Simon, M.S.; Evans, A.T. Timely Use of Probiotics in Hospitalized Adults Prevents Clostridium difficile Infection: A Systematic Review with Meta-Regression Analysis. Gastroenterology 2017, 152, 1889-1900.e9. [CrossRef]

156. Goldenberg, J.Z.; Yap, C.; Lytvyn, L.; Lo, C.K.; Beardsley, J.; Mertz, D.; Johnston, B.C. Probiotics for the prevention of Clostridium difficile-associated diarrhea in adults and children. Cochrane Database Syst. Rev. 2017, 12, CD006095. [CrossRef] [PubMed]

157. Du, C.; Luo, Y.; Walsh, S.; Grinspan, A. Oral Fecal Microbiota Transplant Capsules Are Safe and Effective for Recurrent Clostridioides difficile Infection: A Systematic Review and Meta-Analysis. J. Clin. Gastroenterol. 2021, 55, 300-308. [CrossRef]

158. Beghetti, I.; Panizza, D.; Lenzi, J.; Gori, D.; Martini, S.; Corvaglia, L.; Aceti, A. Probiotics for Preventing Necrotizing Enterocolitis in Preterm Infants: A Network Meta-Analysis. Nutrients 2021, 13, 192. [CrossRef] [PubMed]

159. Pitsillides, L.; Pellino, G.; Tekkis, P.; Kontovounisios, C. The Effect of Perioperative Administration of Probiotics on Colorectal Cancer Surgery Outcomes. Nutrients 2021, 13, 1451. [CrossRef]

160. Rashidi, K.; Razi, B.; Darand, M.; Dehghani, A.; Janmohammadi, P.; Alizadeh, S. Effect of probiotic fermented dairy products on incidence of respiratory tract infections: A systematic review and meta-analysis of randomized clinical trials. Nutr. J. 2021, 20, 61. [CrossRef]

161. Kang, D.W.; Adams, J.B.; Coleman, D.M.; Pollard, E.L.; Maldonado, J.; McDonough-Means, S.; Caporaso, J.G.; Krajmalnik-Brown, R. Long-term benefit of Microbiota Transfer Therapy on autism symptoms and gut microbiota. Sci. Rep. 2019, 9, 5821. [CrossRef]

162. Adams, J.B.; Borody, T.J.; Kang, D.W.; Khoruts, A.; Krajmalnik-Brown, R.; Sadowsky, M.J. Microbiota transplant therapy and autism: Lessons for the clinic. Expert Rev. Gastroenterol. Hepatol. 2019, 13, 1033-1037. [CrossRef]

163. Qureshi, F.; Adams, J.; Hanagan, K.; Kang, D.W.; Krajmalnik-Brown, R.; Hahn, J. Multivariate Analysis of Fecal Metabolites from Children with Autism Spectrum Disorder and Gastrointestinal Symptoms before and after Microbiota Transfer Therapy. J. Pers. Med. 2020, 10, 152. [CrossRef]

164. Kang, D.W.; Adams, J.B.; Vargason, T.; Santiago, M.; Hahn, J.; Krajmalnik-Brown, R. Distinct Fecal and Plasma Metabolites in Children with Autism Spectrum Disorders and Their Modulation after Microbiota Transfer Therapy. mSphere 2020, 5, e00314e00320. [CrossRef] 
165. Solito, A.; Bozzi Cionci, N.; Calgaro, M.; Caputo, M.; Vannini, L.; Hasballa, I.; Archero, F.; Giglione, E.; Ricotti, R.; Walker, G.E.; et al. Supplementation with Bifidobacterium breve BR03 and B632 strains improved insulin sensitivity in children and adolescents with obesity in a cross-over, randomized double-blind placebo-controlled trial. Clin. Nutr. 2021, 40, 4585-4594. [CrossRef]

166. Schellekens, H.; Torres-Fuentes, C.; van de Wouw, M.; Long-Smith, C.M.; Mitchell, A.; Strain, C.; Berding, K.; Bastiaanssen, T.; Rea, K.; Golubeva, A.V.; et al. Bifidobacterium longum counters the effects of obesity: Partial successful translation from rodent to human. EBioMedicine 2021, 63, 103176. [CrossRef]

167. Déchelotte, P.; Breton, J.; Trotin-Picolo, C.; Grube, B.; Erlenbeck, C.; Bothe, G.; Fetissov, S.O.; Lambert, G. The Probiotic Strain, H. alvei HA 4597 ${ }^{\circledR}$ Improves Weight Loss in Overweight Subjects under Moderate Hypocaloric Diet: A Proof-of-Concept, Multicenter Randomized, Double-Blind Placebo-Controlled Study. Nutrients 2021, 13, 1902. [CrossRef]

168. Moludi, J.; Kafil, H.S.; Qaisar, S.A.; Gholizadeh, P.; Alizadeh, M.; Vayghyan, H.J. Effect of probiotic supplementation along with calorie restriction on metabolic endotoxemia, and inflammation markers in coronary artery disease patients: A double blind placebo controlled randomized clinical trial. Nutr. J. 2021, 20, 47. [CrossRef]

169. Rittiphairoj, T.; Pongpirul, K.; Janchot, K.; Mueller, N.T.; Li, T. Probiotics Contribute to Glycemic Control in Patients with Type 2 Diabetes Mellitus: A Systematic Review and Meta-Analysis. Adv. Nutr. 2021, 12, 722-734. [CrossRef]

170. Toejing, P.; Khampithum, N.; Sirilun, S.; Chaiyasut, C.; Lailerd, N. Influence of Lactobacillus paracasei HII01 Supplementation on Glycemia and Inflammatory Biomarkers in Type 2 Diabetes: A Randomized Clinical Trial. Foods 2021, 10, 1455. [CrossRef] [PubMed]

171. Kumar, S.; Kumar, R.; Rohilla, L.; Jacob, N.; Yadav, J.; Sachdeva, N. A high potency multi-strain probiotic improves glycemic control in children with new-onset type 1 diabetes mellitus: A randomized, double-blind, and placebo-controlled pilot study. Pediatr. Diabetes 2021. [CrossRef]

172. Rufino, M.N.; da Costa, A.L.; Jorge, E.N.; Paiano, V.F.; Camparoto, M.L.; Keller, R.; Bremer-Neto, H. Synbiotics improve clinical indicators of ulcerative colitis: Systematic review with meta-analysis. Nutr. Rev. 2021, nuab017. [CrossRef]

173. Chen, H.T.; Huang, H.L.; Xu, H.M.; Luo, Q.L.; He, J.; Li, Y.Q.; Zhou, Y.L.; Nie, Y.Q.; Zhou, Y.J. Fecal microbiota transplantation ameliorates active ulcerative colitis. Exp. Ther. Med. 2020, 19, 2650-2660. [CrossRef] [PubMed]

174. Wang, I.K.; Yen, T.H.; Hsieh, P.S.; Ho, H.H.; Kuo, Y.W.; Huang, Y.Y.; Kuo, Y.L.; Li, C.Y.; Lin, H.C.; Wang, J.Y. Effect of a Probiotic Combination in an Experimental Mouse Model and Clinical Patients With Chronic Kidney Disease: A Pilot Study. Front. Nutr. 2021, 8, 661794. [CrossRef] [PubMed]

175. Yoon, W.; Park, S.H.; Lee, J.S.; Byeon, J.H.; Kim, S.H.; Lim, J.; Yoo, Y. Probiotic mixture reduces gut inflammation and microbial dysbiosis in children with atopic dermatitis. Australas. J. Dermatol. 2021, 62, 386-392. [CrossRef] [PubMed]

176. Tang, M.L.; Ponsonby, A.L.; Orsini, F.; Tey, D.; Robinson, M.; Su, E.L.; Licciardi, P.; Burks, W.; Donath, S. Administration of a probiotic with peanut oral immunotherapy: A randomized trial. J. Allergy Clin. Immunol. 2015, 135, 737-744.e8. [CrossRef] [PubMed]

177. Dunn Galvin, A.; McMahon, S.; Ponsonby, A.L.; Hsiao, K.C.; Tang, M.L.K.; PPOIT Study Team. The longitudinal impact of probiotic and peanut oral immunotherapy on health-related quality of life. Allergy 2018, 73, 560-568. [CrossRef] [PubMed]

178. Jing, W.; Liu, Q.; Wang, W. Bifidobacterium bifidum TMC3115 ameliorates milk protein allergy in by affecting gut microbiota: A randomized double-blind control trial. J. Food Biochem. 2020, 44, e13489. [CrossRef]

179. Anania, C.; Di Marino, V.P.; Olivero, F.; De Canditiis, D.; Brindisi, G.; Iannilli, F.; De Castro, G.; Zicari, A.M.; Duse, M. Treatment with a Probiotic Mixture Containing Bifidobacterium animalis Subsp. Lactis BB12 and Enterococcus faecium L3 for the Prevention of Allergic Rhinitis Symptoms in Children: A Randomized Controlled Trial. Nutrients 2021, 13, 1315. [CrossRef]

180. Miraglia Del Giudice, M.; Indolfi, C.; Capasso, M.; Maiello, N.; Decimo, F.; Ciprandi, G. Bifidobacterium mixture (B longum BB536, $B$ infantis M-63, B breve M-16V) treatment in children with seasonal allergic rhinitis and intermittent asthma. Ital. J. Pediatr. 2017, 43, 25. [CrossRef]

181. Ahanchian, H.; Jafari, S.A.; Ansari, E.; Ganji, T.; Kiani, M.A.; Khalesi, M.; Momen, T.; Kianifar, H. A multi-strain Synbiotic may reduce viral respiratory infections in asthmatic children: A randomized controlled trial. Electron. Physician 2016, 8, $2833-2839$. [CrossRef]

182. Sandoval, F.; Faleiros, S.; Cabello, R.; Díaz-Dosque, M.; Rodríguez, G.; Escobar, A. The consumption of milk supplemented with probiotics decreases the occurrence of caries and the salivary concentration of h $\beta \mathrm{D}-3$ in children. Clin. Oral Investig. 2021, 25, 3823-3830. [CrossRef]

183. Duysburgh, C.; Van den Abbeele, P.; Morera, M.; Marzorati, M. Lacticaseibacillus rhamnosus GG and Saccharomyces cerevisiae boulardii supplementation exert protective effects on human gut microbiome following antibiotic administration in vitro. Benef. Microbes 2021, 30, 1-16. [CrossRef]

184. Hu, W.; Lu, W.; Li, L.; Zhang, H.; Lee, Y.K.; Chen, W.; Zhao, J. Both living and dead Faecalibacterium prausnitzii alleviate house dust mite-induced allergic asthma through the modulation of gut microbiota and short-chain fatty acid production. J. Sci. Food Agric. 2021. [CrossRef]

185. Wang, W.; Luo, X.; Zhang, Q.; He, X.; Zhang, Z.; Wang, X. Bifidobacterium infantis Relieves Allergic Asthma in Mice by Regulating Th1/Th2. Med. Sci. Monit. 2020, 26, e920583. [CrossRef]

186. Zhang, J.; Ma, J.; Li, Q.; Su, H.; Sun, X. Exploration of the effect of mixed probiotics on microbiota of allergic asthma mice. Cell. Immunol. 2021, 367, 104399. [CrossRef] 
187. Xue, J.M.; Ma, F.; An, Y.F.; Suo, L.M.; Geng, X.R.; Song, Y.N.; Mo, L.H.; Luo, X.Q.; Zhang, X.W.; Liu, D.B.; et al. Probiotic extracts ameliorate nasal allergy by inducing interleukin-35-producing dendritic cells in mice. Int. Forum Allergy Rhinol. 2019, 9, $1289-1296$. [CrossRef]

188. Zhang, Q.; Fan, X.Y.; Cao, Y.J.; Zheng, T.T.; Cheng, W.J.; Chen, L.J.; Lv, X.C.; Ni, L.; Rao, P.F.; Liang, P. The beneficial effects of Lactobacillus brevis FZU0713-fermented Laminaria japonica on lipid metabolism and intestinal microbiota in hyperlipidemic rats fed with a high-fat diet. Food Funct. 2021, 12, 7145-7160. [CrossRef]

189. Okada, Y.; Tsuzuki, Y.; Sugihara, N.; Nishii, S.; Shibuya, N.; Mizoguchi, A.; Itoh, S.; Tanemoto, R.; Inaba, K.; Hanawa, Y.; et al. Novel probiotic yeast from Miso promotes regulatory dendritic cell IL-10 production and attenuates DSS-induced colitis in mice. J. Gastroenterol. 2021, 56, 829-842. [CrossRef]

190. O'Morain, V.L.l.; Chan, Y.H.; Williams, J.O.; Alotibi, R.; Alahmadi, A.; Rodrigues, N.P.; Plummer, S.F.; Hughes, T.R.; Michael, D.R.; Ramji, D.P. The Lab4P Consortium of Probiotics Attenuates Atherosclerosis in LDL Receptor Deficient Mice Fed a High Fat Diet and Causes Plaque Stabilization by Inhibiting Inflammation and Several Pro-atherogenic Processes. Mol. Nutr. Food Res. 2021, e2100214. [CrossRef]

191. Mahajan, E.; Sinha, S.; Bhatia, A.; Sehgal, R.; Medhi, B. Evaluation of the effect of probiotic as add-on therapy with conventional therapy and alone in malaria induced mice. BMC Res. Notes 2021, 14, 246. [CrossRef]

192. Scott, B.M.; Gutiérrez-Vázquez, C.; Sanmarco, L.M.; da Silva Pereira, J.A.; Li, Z.; Plasencia, A.; Hewson, P.; Cox, L.M.; O’Brien, M.; Chen, S.K.; et al. Self-tunable engineered yeast probiotics for the treatment of inflammatory bowel disease. Nat. Med. 2021, 27, 1212-1222. [CrossRef]

193. Huang, H.; Li, K.; Lee, Y.; Chen, M. Preventive Effects of Lactobacillus Mixture against Chronic Kidney Disease Progression through Enhancement of Beneficial Bacteria and Downregulation of Gut-Derived Uremic Toxins. J. Agric. Food Chem. 2021, 69, 7353-7366. [CrossRef] [PubMed]

194. Yang, B.; Huang, Z.; He, Z.; Yue, Y.; Zhou, Y.; Ross, R.P.; Stanton, C.; Zhang, H.; Zhao, J.; Chen, W. Protective effect of Bifidobacterium bifidum FSDJN7O5 and Bifidobacterium breve FHNFQ23M3 on diarrhea caused by enterotoxigenic Escherichia coli. Food Funct. 2021, 12, 7271-7282. [CrossRef] [PubMed]

195. Wang, X.; Fukui, H.; Ran, Y.; Xu, X.; Ebisutani, N.; Nakanishi, T.; Tanaka, Y.; Maeda, A.; Makizaki, Y.; Tomita, T.; et al. Probiotic Bifidobacterium bifidum G9-1 Has a Preventive Effect on the Acceleration of Colonic Permeability and M1 Macrophage Population in Maternally Separated Rats. Biomedicines 2021, 9, 641. [CrossRef] [PubMed]

196. Zheng, D.; Liwinski, T.; Elinav, E. Interaction between microbiota and immunity in health and disease. Cell Res. 2020, 30, 492-506. [CrossRef] [PubMed]

197. Kim, C.H. Control of lymphocyte functions by gut microbiota-derived short-chain fatty acids. Cell. Mol. Immunol. 2021, 18, 1161-1171. [CrossRef]

198. Beller, A.; Kruglov, A.; Durek, P.; von Goetze, V.; Werner, K.; Heinz, G.A.; Ninnemann, J.; Lehmann, K.; Maier, R.; Hoffmann, U.; et al. Specific microbiota enhances intestinal IgA levels by inducing TGF- $\beta$ in T follicular helper cells of Peyer's patches in mice. Eur. J. Immunol. 2020, 50, 783-794. [CrossRef]

199. Takeuchi, T.; Ohno, H. Reciprocal regulation of IgA and the gut microbiota: A key mutualism in the intestine. Int. Immunol. 2021, dxab049. [CrossRef]

200. Huus, K.E.; Peterse, C.; Finlay, B.B. Diversity and dynamism of IgA-microbiota interactions. Nat. Rev. Immunol. 2021, 21, 514-525 [CrossRef]

201. Nakajima, A.; Vogelzang, A.; Maruya, M.; Miyajima, M.; Murata, M.; Son, A.; Kuwahara, T.; Tsuruyama, T.; Yamada, S.; Matsuura, M.; et al. IgA regulates the composition and metabolic function of gut microbiota by promoting symbiosis between bacteria. $J$. Exp. Med. 2018, 215, 2019-2034. [CrossRef]

202. Shapiro, J.M.; de Zoete, M.R.; Palm, N.W.; Laenen, Y.; Bright, R.; Mallette, M.; Bu, K.; Bielecka, A.A.; Xu, F.; Hurtado-Lorenzo, A.; et al. Immunoglobulin A Targets a Unique Subset of the Microbiota in Inflammatory Bowel Disease. Cell Host Microbe 2021, 29, 83-93.e3. [CrossRef]

203. Pabst, O.; Slack, E. IgA and the intestinal microbiota: The importance of being specific. Mucosal Immunol. 2020, $13,12-21$. [CrossRef]

204. Palm, N.W.; de Zoete, M.R.; Cullen, T.W.; Barry, N.A.; Stefanowski, J.; Hao, L.; Degnan, P.H.; Hu, J.; Peter, I.; Zhang, W.; et al. Immunoglobulin A coating identifies colitogenic bacteria in inflammatory bowel disease. Cell 2014, 158, 1000-1010. [CrossRef]

205. Kawamoto, S.; Maruya, M.; Kato, L.M.; Suda, W.; Atarashi, K.; Doi, Y.; Tsutsui, Y.; Qin, H.; Honda, K.; Okada, T. Foxp3 ${ }^{+}$T cells regulate immunoglobulin A selection and facilitate diversification of bacterial species responsible for immune homeostasis. Immunity 2014, 41, 152-165. [CrossRef] [PubMed]

206. Beck, K.; Ohno, H.; Satoh-Takayama, N. Innate Lymphoid Cells: Important Regulators of Host-Bacteria Interaction for Border Defense. Microorganisms 2020, 8, 1342. [CrossRef] [PubMed]

207. Hardman, C.S.; Chen, Y.L.; Salimi, M.; Jarrett, R.; Johnson, D.; Järvinen, V.J.; Owens, R.J.; Repapi, E.; Cousins, D.J.; Barlow, J.L.; et al. CD1a presentation of endogenous antigens by group 2 innate lymphoid cells. Sci. Immunol. 2017, 2, eaan5918. [CrossRef]

208. Wang, Y.; Wu, Y.; Sailike, J.; Sun, X.; Abuduwaili, N.; Tuoliuhan, H.; Yusufu, M.; Nabi, X.H. Fourteen composite probiotics alleviate type 2 diabetes through modulating gut microbiota and modifying M1/M2 phenotype macrophage in $\mathrm{db} / \mathrm{db}$ mice. Pharmacol. Res. 2020, 161, 105150. [CrossRef] 
209. Zhang, Q.; Hao, H.; Xie, Z.; Cheng, Y.; Yin, Y.; Xie, M.; Huang, H.; Gao, J.; Liu, H.; Tong, C.; et al. M2 macrophages infusion ameliorates obesity and insulin resistance by remodeling inflammatory/macrophages' homeostasis in obese mice. Mol. Cell. Endocrinol. 2017, 443, 63-71. [CrossRef]

210. Orliaguet, L.; Ejlalmanesh, T.; Alzaid, F. Metabolic and Molecular Mechanisms of Macrophage Polarisation and Adipose Tissue Insulin Resistance. Int. J. Mol. Sci. 2020, 21, 5731. [CrossRef]

211. Vega-Galaviz, D.; Vecchyo-Tenorio, G.D.; Alcántara-Suárez, R.; Méndez-García, L.A.; Sánchez-Del Real, A.L.; Villalobos-Molina, R.; Fragoso, J.M.; León-Cabrera, S.; Ostoa-Saloma, P.; Pérez-Tamayo, R.; et al. M2 macrophage immunotherapy abolishes glucose intolerance by increasing IL-10 expression and AKT activation. Immunotherapy 2020, 12, 9-24. [CrossRef] [PubMed]

212. Đanić, M.; Stanimirov, B.; Pavlović, N.; Goločorbin-Kon, S.; Al-Salami, H.; Stankov, K.; Mikov, M. Pharmacological Applications of Bile Acids and Their Derivatives in the Treatment of Metabolic Syndrome. Front. Pharmacol. 2018, 9, 1382. [CrossRef]

213. Wang, L.; Gong, Z.; Zhang, X.; Zhu, F.; Liu, Y.; Jin, C.; Du, X.; Xu, C.; Chen, Y.; Cai, W.; et al. Gut microbial bile acid metabolite skews macrophage polarization and contributes to high-fat diet-induced colonic inflammation. Gut Microbes 2020, $12,1819155$. [CrossRef] [PubMed]

214. Wei, M.; Huang, F.; Zhao, L.; Zhang, Y.; Yang, W.; Wang, S.; Li, M.; Han, X.; Ge, K.; Qu, C.; et al. A dysregulated bile acid-gut microbiota axis contributes to obesity susceptibility. EBioMedicine 2020, 55, 102766. [CrossRef] [PubMed]

215. Bellinger, D.C. Very low lead exposures and children's neurodevelopment. Curr. Opin. Pediatr. 2008, 20, 172-177. [CrossRef] [PubMed]

216. Dietert, R.R.; Piepenbrink, M.S. Lead and immune function. Crit. Rev. Toxicol. 2006, 36, 359-385. [CrossRef]

217. Bellinger, D.C. Lead Contamination in Flint-An Abject Failure to Protect Public Health. N. Engl. J. Med. 2016, $374,1101-1103$. [CrossRef]

218. Hanna-Attisha, M.; Lanphear, B.; Landrigan, P. Lead Poisoning in the 21st Century: The Silent Epidemic Continues. Am. J. Public Health 2018, 108, 1430. [CrossRef]

219. Bertók, L. Effect of sulfhydryl compound on the lead acetate-induced endotoxin hypersensitivity of rats. J. Bacteriol. 1968, 95, 1974-1975. [CrossRef]

220. Faith, R.E.; Luster, M.I.; Kimmel, C.A. Effect of chronic developmental lead exposure on cell-mediated immune functions. Clin. Exp. Immunol. 1979, 35, 413-420.

221. Miller, T.E.; Golemboski, K.A.; Ha, R.S.; Bunn, T.; Sanders, F.S.; Dietert, R.R. Developmental exposure to lead causes persistent immunotoxicity in Fischer 344 rats. Toxicol. Sci. 1998, 42, 129-135. [CrossRef]

222. Bunn, T.L.; Parsons, P.J.; Kao, E.; Dietert, R.R. Exposure to lead during critical windows of embryonic development: Differential immunotoxic outcome based on stage of exposure and gender. Toxicol. Sci. 2001, 64, 57-66. [CrossRef]

223. Di Lenardo, T.Z.; Ward, B.J.; Pillet, S.; Mann, K.; Bornman, R.; Obida, M.; Chevrier, J. Exposure to lead and vaccine-specific IgG titers in South African children participating in the Venda Health Examination of Mothers, Babies and their Environment (VHEMBE): A longitudinal study. Environ. Res. 2020, 180, 108794. [CrossRef]

224. Liu, W.; Feng, H.; Zheng, S.; Xu, S.; Massey, I.Y.; Zhang, C.; Wang, X.; Yang, F. Pb Toxicity on Gut Physiology and Microbiota. Front. Physiol. 2021, 12, 574913. [CrossRef]

225. Zhai, Q.; Qu, D.; Feng, S.; Yu, Y.; Yu, L.; Tian, F.; Zhao, J.; Zhang, H.; Chen, W. Oral Supplementation of Lead-Intolerant Intestinal Microbes Protects Against Lead (Pb) Toxicity in Mice. Front. Microbiol. 2020, 10, 3161. [CrossRef]

226. Finlay, B.B.; Amato, K.R.; Azad, M.; Blaser, M.J.; Bosch, T.C.G.; Chu, H.; Dominguez-Bello, M.G.; Ehrlich, S.D.; Elinav, E.; Geva-Zatorsky, N.; et al. The hygiene hypothesis, the COVID pandemic, and consequences for the human microbiome. Proc. Natl. Acad. Sci. USA 2021, 118, e2010217118. [CrossRef]

227. Dietert, R.R. The microbiological basis of human superorganism freedom. Am. J. Biomed. Sci. Res. 2021, 13, 653-661. [CrossRef]

228. Blaser, M.J. Missing Microbes: How the Overuse of Antibiotics Is Fueling Our Modern Plagues; Henry Holt and Company: New York, NY, USA, 2014; 288p, ISBN 978-0805098105.

229. Bilello, J.; Okereke, I. Impact of Environmental and Pharmacologic Changes on the Upper Gastrointestinal Microbiome. Biomedicines 2021, 9, 617. [CrossRef] [PubMed]

230. Boem, F.; Nannini, G.; Amedei, A. Not just 'immunity': How the microbiota can reshape our approach to cancer immunotherapy. Immunotherapy 2020, 12, 407-416. [CrossRef] 